\title{
EURODYN 2020
}

XI International Conference on Structural Dynamics

\section{PROCEEDINGS}

\section{Volume I}

M. Papadrakakis, M. Fragiadakis, C. Papadimitriou (Eds.) 



\section{EURODYN 2020}

Proceedings of the XI International Conference on Structural Dynamics Streamed from Athens, Greece

23-26 November 2020

Edited by:

M. Papadrakakis

National Technical University of Athens, Greece

\section{Fragiadakis}

National Technical University of Athens, Greece

\section{Papadimitriou}

University of Thessaly, Greece

\section{A publication of:}

Institute of Structural Analysis and Antiseismic Research School of Civil Engineering

National Technical University of Athens (NTUA)

Greece 


\section{EURODYN 2020}

XI International Conference on Structural Dynamics

M. Papadrakakis, M. Fragiadakis, C. Papadimitriou (Eds.)

First Edition, September 2020

(c) The authors

ISBN (set): 978-618-85072-2-7

ISBN (vol I): 978-618-85072-0-3 


\section{PREFACE}

This volume contains the full-length papers accepted for presentation at the $\mathrm{XI}$ International Conference on Structural Dynamics EURODYN 2020, streamed online from Athens, Greece on November 23-26, 2020.

EURODYN Conference Series is organized under the auspices of the European Association of Structural Dynamics (EASD). EASD was founded in 1990 as a joint European initiative of experts in Structural Dynamics, with the purpose of sponsoring and overseeing the organization of the EURODYN conferences, scheduled to take place with a three-year interval. The first EURODYN Conference was held in Bochum in 1990, organized by the founding president of EASD Prof. Wilfried Krätzig. Following Bochum, the conferences were held in Trondheim (1993), Florence (1996), Prague (1999), Munich (2002), Paris, (2005), Southampton (2008), Leuven (2011), Porto (2014), Rome in 2017 and this year in Athens, the city where the EURODYN 2020 conference would have taken place in June 2020.

In view of the first signs of the COVID-19 pandemic at the beginning of this year, we were forced to postpone the conference dates at the end of November 2020. This was expected to give the opportunity to the participants to attend the conference either physically or remotely. Unfortunately, and contrary to what we had all anticipated, the COVID-19 was still around at the end of June 2020, and hence we were left with no other choice but to abandon the idea of a physical conference and organize a fully online event. This transition was very painful and created many administration complications. Nevertheless, EASD and the organizing committee have seen this sanitary crisis as an opportunity to organize a different type of event and to propose a new approach for scientific collaboration and communication that respects both the legacy of the conference series and the health of the members of the European Community of Structural Dynamics.

EURODYN conferences have been established as the top scientific events in the area of theoretical, numerical and experimental Structural Dynamics worldwide and are highly-anticipated every three years by the international community of Structural Dynamics. For the 2020 edition of EURODYN series, more than 1000 abstracts were submitted, of which 830 were selected for presentation and among them 400 fulllength papers were accepted for publication in the EASD Open Access Procedia, indexed by Scopus Database.

The editors of this volume would like to thank all authors for their contributions. Special thanks go to the 88 colleagues who were involved in the organization of 38 Minisymposia and to the reviewers who contributed to the scientific quality of this e-book with their work.

We would particularly like to thank the Members of the EASD Executive Board, and especially Álvaro Cunha, the President of EASD, Guido De Roeck, the Honorary Chairman of EURODYN 2020 and Fabrizio Vestroni the Chair of the EURODYN 2017, for their valuable advice, suggestions and interest, during the three-year preparation period of EURODYN 2020. Their contributions were significant to the successful outcome of this undertaking.

\section{Manolis Papadrakakis}

National Technical University of Athens, Greece

\section{Michalis Fragiadakis}

National Technical University of Athens, Greece

\section{Costas Papadimitriou}

University of Thessaly, Greece 


\section{ACKNOWLEDGEMENTS}

The conference organizers acknowledge the support towards the organization of the "XI International Conference on Structural Dynamics", to the following organizations: European Association for Structural Dynamics (EASD), Greek Association for Computational Mechanics (GRACM), Hellenic Society for Earthquake Engineering (HSEE), School of Civil Engineering, National University of Athens (NTUA).

\section{Plenary, Semi-Plenary Speakers and Minisymposia Organizers}

We would also like to thank the Plenary and Semi-Plenary Speakers and the Minisymposia Organizers for their help in the setting up of a high standard Scientific Programme.

Plenary Speakers: Geert Degrande, Tracy Kijewski-Correa, Yi Qing Ni

Semi-Plenary Speakers: Eleni Chatzi, Joel P. Conte, Geert Lombaert, Andrei Metrikine, Sotirios Natsiavas, Filippo Ubertini

MS Organizers: I. Antoniadis, M. Arnst, K. Bakalis, B. Balachandran, C.C. Baniotopoulos, M. Barbato, J. Beck, M. Beer, G. Bonnet, C. Borri, C. Boutin, L. Bruno, E. Caetano, F. Casciati, C.A. Castiglioni, E. Chatzi, A. Cicirello, F. Clementi, D. Clouteau, J. Conte, M. Corradi, A. Cunha, G. De Roeck, G. Degrande, V. Denoël, D. Duhamel, J. Edelmann, D. Forcellini, A. Formisano, F. Foti, M. Fragiadakis, V. C. Fragkoulis, V. Fragkoulis, C. Gentile, R. Ghanem, D. Giagopoulos, A. Giaralis, P.B. Gonçalves, R. Höffer, A. Kanyilmaz, I. A. Kougioumtzoglou, S. Lenci, G. Lombaert, F. Magalhães, C. Maniatakis, E. Marino, T. Mazilu, C. E. N. Mazzilli, V. Melissianos, A. Metrikine, A.V. Metrikine, G. Milani, I.P. Mitseas, B. Moaveni, C. Moutinho, H. Mouzakis, H. P. Mouzakis, G. Müller, J. Naprstek, S. Natsiavas, P. Omenzetter, C. Papadimitriou, M. Papadrakakis, I. Papaioannou, A. Pavic, F. Pellicano, F. Perotti, M. Ploechl, I. Psycharis, G. Rega, J. Rodellar, E. Sapountzakis, JF. Semblat, V. Sepe, C. Soize, S. Sorokin, C. Spyrakos, A. Taflanidis, F. Tubino, D. Vamvatsikos, K.N. van Dalen, P. Van den Broeck, K. Van Nimmen, M. Vasta, P-M. Vasta, I. Vayas, D. Wagg, K. Worden, W.M. Zhai 


\section{SUMMARY}

Preface iii

Acknowledgements iv

Contents viii

\section{VOLUME I}

Minisymposia

MS 1: ADVANCES IN COMPUTATIONAL STRUCTURAL DYNAMICS .1

Organized by B. Balachandran, D. Duhamel, D. Giagopoulos, S. Natsiavas

MS 2: NON-LINEAR DYNAMICS .180

Organized by J. Naprstek, G. Rega

MS 3: DYNAMIC BUCKLING

Organized by P.B. Gonçalves, F. Pellicano, C. E. N. Mazzilli

MS 4: DYNAMICS OF COMPOSITE MATERIALS

Organized by G. Bonnet, C. Boutin, S. Lenci

MS 5: DYNAMIC FLUID-STRUCTURE INTERACTION

MS 6: VEHICLE DYNAMICS

Organized by M. Ploechl, J. Edelmann

MS 7: SYSTEM IDENTIFICATION AND DAMAGE DETECTION

Organized by E. Chatzi, G. De Roeck

MS 8: STRUCTURAL HEALTH MONITORING

Organized by J. Conte, A. Cunha, G. Lombaert, B. Moaveni, P. Omenzetter, C. Papadimitriou

MS 9: STRUCTURAL CONTROL

Organized by F. Casciati, J. Rodellar

MS 10: ADVANCES ON INERTER-BASED STRUCTURAL VIBRATION CONTROL 1501

Organized by A. Giaralis, A. Taflanidis

MS 11: BRIDGE DYNAMICS

MS 12: FOOTBRIDGE VIBRATIONS

Organized by E. Caetano, F. Tubino, P. Van den Broeck, K. Van Nimmen

MS 13: HUMAN INDUCED VIBRATIONS IN FLOORS, STAIRCASES AND STADIA 1896

Organized by L. Bruno, A. Pavic 
Organized by V. Denoël, F. Foti, F. Perotti

MS 15: DYNAMICS OF ON- AND OFF-SHORE WIND ENERGY STRUCTURES (WES)

Organized by C. Borri, E. Marino, C.C. Baniotopoulos, R. Höffer, F. Magalhães

MS 16: VIBRATION-BASED ASSESSMENT AND SHM OF CULTURAL HERITAGE STRUCTURES

Organized by C. Gentile

MS 17: VIBRATIONS DUE TO CONSTRUCTION AND INDUSTRIAL ACTIVITIES

Organized by C. Moutinho

\section{VOLUME II}

Minisymposia

MS 18: VIBRO-ACOUSTICS

Organized by S. Sorokin

MS 19: BLAST AND IMPACT LOADS

MS 20: MOVING LOADS

Organized by T. Mazilu, A.V. Metrikine, K.N. van Dalen, W.M. Zhai

MS 21: TRAFFIC INDUCED VIBRATIONS

Organized by G. Degrande, G. Lombaert, G. Müller

MS 22: DYNAMIC SOIL-STRUCTURE INTERACTION AND WAVE PROPAGATION

Organized by D. Clouteau, A. Metrikine, G. Müller, J-F. Semblat

MS 23: ASSESSMENT OF INDUSTRIAL STRUCTURES AND INFRASTRUCTURE UNDER NATURAL HAZARDS

Organized by K. Bakalis, V. Melissianos, D. Vamvatsikos

MS 24: SEISMIC PROTECTION OF STEEL STRUCTURES BY MEANS OF DISSIPATIVE SYSTEMS AND COMPONENTS

Organized by C.A. Castiglioni, A. Kanyilmaz, I. Psycharis, H. P. Mouzakis, I. Vayas

MS 25: EXPERIMENTAL EARTHQUAKE ENGINEERING

Organized by M. Fragiadakis, H. Mouzakis

MS 26: UQ AND PROBABILISTIC LEARNING IN COMPUTATIONAL DYNAMICS

Organized by M. Arnst, R. Ghanem, C. Soize

MS 27: STOCHASTIC DYNAMICS AND RELIABILITY ANALYSIS OF STRUCTURAL AND MECHANICAL SYSTEMS UNDER ENVIRONMENTAL EXCITATION

Organized by M. Barbato, M. Vasta 
Organized by M. Barbato, V. Sepe, P-M. Vasta

MS 29: BAYESIAN UPDATING, FILTERING AND INVERSION FOR DYNAMIC SYSTEMS

Organized by J. Beck, A. Taflanidis, I. Papaioannou

MS 30: RECENT ADVANCES IN PERFORMANCE-BASED ENGINEERING AND DESIGN OF STRUCTURES AND CIVIL INFRASTRUCTURE SYSTEMS SUBJECTED TO SINGLE OR MULTIPLE HAZARDS .3607

Organized by M. Barbato, J. Conte

MS 31: EUROPEAN ETN “DYNAMIC VIRTUALISATION: MODELLING PERFORMANCE OF ENGINEERING STRUCTURES" (DYVIRT)

Organized by M. Beer, V. Fragkoulis, D. Wagg, K. Worden

MS 32: COMPUTATIONAL METHODS FOR STOCHASTIC DYNAMICS

Organized by M. Beer, V. C. Fragkoulis, I. A. Kougioumtzoglou, I.P. Mitseas

MS 33: NUMERICAL SIMULATIONS FOR EARTHQUAKE-RESILIENT SYSTEMS

Organized by D. Forcellini

MS 34: VIBRATION ABSORPTION

Organized by I. Antoniadis, E. Sapountzakis

MS 35: NEW TRENDS IN THE COMPUTATIONAL AND EXPERIMENTAL STRUCTURAL DYNAMICS FOR THE PRESERVATION OF HISTORICAL MASONRY STRUCTURES IN SEISMIC AREAS

Organized by F. Clementi, A. Formisano, G. Milani

MS 36: DAMPING MODELLING AND EXPERIMENTS

Organized by A. Cicirello

MS 37: CONSERVATION, RETROFIT AND STRENGTHENING OF EXISTING STRUCTURES: INNOVATIONS IN APPLIED METHODS AND MATERIALS

Organized by M. Corradi, C. Maniatakis, C. Spyrakos

MS 38: GENERAL SESSION ON STRUCTURAL DYNAMICS, STABILITY AND VIBRATIONS 4418

Organized by G. De Roeck, M. Fragiadakis, C. Papadimitriou, M. Papadrakakis 


\section{CONTENTS}

\section{VOLUME I}

\section{Minisymposia}

\section{MS 1: ADVANCES IN COMPUTATIONAL STRUCTURAL DYNAMICS}

A MODE MATCHING TECHNIQUE FOR THE SEISMIC RESPONSE OF LIQUID STORAGE TANKS INCLUDING SOIL-STRUCTURE INTERACTION

Apostolos Tsouvalas, Timo Molenkamp, Khairina Canny, David Kroon, Marco Versluis, Yaxi Peng, Andrei Metrikine

APPLICATION OF THE WAVE FINITE ELEMENT METHOD TO MULTI-SPAN BRIDGES 15

Gabriele Paratore, Tien Hoang, Gilles Foret, Maria Pina Limongelli, Denis Duhame

A VARIATIONAL APPROACH TO ASYNCHRONOUS TIME-INTEGRATION OF STRUCTURAL DYNAMICS PROBLEMS IN THE CONTEXT OF FETI AND SPURIOUS OSCILLATIONS ON THE INTERFACES Andreas Seibold, Daniel Rixen

DEVELOPMENT AND VALIDATION OF A MULTIBODY DYNAMICS MODEL FOR THE ASSESSMENT OF THE SEISMIC RETROFIT POTENTIAL OF BRIDGE EXPANSION JOINTS

Michael Tahedl, Andreas Taras, Fredrik Borchsenius, Daniel Rill

AN DELAYED FREQUENCY PRECONDITIONER APPROACH FOR SPEEDING-UP FREQUENCY RESPONSE COMPUTATION OF STRUCTURAL COMPONENTS

Guilherme Jenovencio, Arul Sivasankar, Zeeshan Saeed, Daniel Rixen

NONLINEAR FORCE LAW SELECTION AND PARAMETER UPDATE FOR A CANTILEVER BEAM WITH PERIODICALLY REPEATED IMPACTS

Alexandros Arailopoulos, Dimitrios Giagopoulos

SIMULATION-LEAN TRAINING-SETS FOR HYPER-REDUCTION OF PARAMETRIC GEOMETRIC NON-LINEAR STRUCTURES 80

Christian H. Meyer, Daniel J. Rixen

REGULARIZATION METHOD TO INCLUDE MATERIAL SOFTENING IN FIBER BEAM-COLUMN ELEMENTS FOR SEISMIC PERFORMANCE ASSESSMENT OF STEEL FRAMES

Sebastián Pozo, Bryam Astudillo, Esteban Samaniego, Francisco Flores

EFFICIENCY OF 1D CNNS IN FINITE ELEMENT MODEL PARAMETER ESTIMATION USING SYNTHETIC DYNAMIC RESPONSES

Mohammad Almutairi, Onur Avci, Nikolaos Nikitas

INFLUENCE OF SLENDERNESS RATIO IN THE MODAL ANALYSIS BY ANALYTICAL FORMULATION 121

Jonas Falcão, Rodolfo Carvalho, Renan Ribeiro, Ledymar Moreno, José De Brito 
ON SPACE-TIME FORMULATIONS IN STRUCTURAL MECHANICS USING THE PROPER GENERALIZED

DECOMPOSITION 136

Franz Bamer, Nima Shirafkan, Abdelbacet Oueslati, Marcus Stoffel, Géry De Saxcé, Bernd Markert

ISOGEOMETRIC COLLOCATION METHODS FOR THE DYNAMICS OF THREE-DIMENSIONAL GEOMETRICALLY

EXACT BEAMS

Enzo Marino, Josef Kiendl, Laura De Lorenzis

ANALYTICAL-NUMERICAL MODELING OF FLEXIBLE PYLONS FOR STRUCTURAL HEALTH MONITORING 168

George D. Manolis, Georgios Dadoulis, Stylianos Pardalopoulos, Kosmas Dragos

\section{MS 2: NON-LINEAR DYNAMICS}

NONLINEAR DYNAMICS OF A NEGATIVE STIFFNESS OSCILLATOR: EXPERIMENTAL IDENTIFICATION AND MODEL UPDATING 180

Dario Anastasio, Alessandro Fasana, Luigi Garibaldi, Stefano Marchesiello

GEOMETRICALLY NONLINEAR FORCED VIBRATIONS OF MULTIPLE-STEPPED EULER-BERNOULLI BEAMS

Issam El Hantati, Ahmed Adri, Hatim Fakhreddine, Said Rifai, Rhali Benamar

NONSMOOTH MODAL ANALYSIS WITH BOUNDARY ELEMENT METHOD 205

Tianzheng Lu, Mathias Legrand

SUBSONIC STALL FLUTTER ANALYSIS IN 2D BLADE CASCADE USING HYBRID BOUNDARY ELEMENT METHOD .... 213 Chandra Shekhar Prasad, Ludek Pesek

GEOMETRICALLY NON-LINEAR FREE AND FORCED VIBRATION OF C-F-C-F RECTANGULAR PLATE AT LARGE TRANSVERSE AMPLITUDES

Abdelfattah Majid, El Mehdi Abdeddine, Khalid Zarbane, Zitouni Beidouri

NONLINEAR LONGITUDINAL FREE VIBRATION OF UNIFORM RODS AND RODS WITH SECTIONS VARYING EXPONENTIALLY

EL Mehdi Abdeddine, Abdelfattah Majid, Zitouni Beidouri, Khalid Zarbane

DYNAMIC RESPONSE OF TWO INTERACTING EXTENSIBLE BARS IN FRICTIONAL CONTACT

Timo Molenkamp, Athanasios Tsetas, Apostolos Tsouvalas, Andrei Metrikine

NUMERICAL STUDY OF DYNAMIC PROPERTIES OF A SELECTED MATERIAL LAYER OF BULLETPROOF SHIELDS .... 265 Miroslaw Bocian, Krzysztof Jamroziak, Maciej Kulisiewicz, Joanna Pach, Dariusz Pyka

MEASUREMENTS OF NONLINEAR VIBRATIONS OF A BEAM SUBJECTED TO TWO BROADBAND CORRELATED RANDOM EXCITATIONS

Sébastien Talik, Maxence Claeys, Jean-Pierre Lambelin, Jean-Jacques Sinou 
VIBRATION POWER FLOW TRANSMISSION BETWEEN NONLINEARLY COUPLED OSCILLATORS WITH DUAL FORCE EXCITATIONS

Baiyang Shi, Chendi Zhu, Jian Yang

STOCHASTIC DYNAMICAL RESPONSE OF A NON-SMOOTH DYNAMICAL SYSTEM UNDER FILTERED WHITE NOISE

Saeed Gheisari Hasnijeh, Arvid Naess

A NEW TIME INTEGRATION SCHEME IN MULTIBODY DYNAMICS INVOLVING FRICTIONAL IMPACT BASED ON A RETURN MAP TO NON-FLAT CONFIGURATION MANIFOLDS 303

Elias Paraskevopoulos, Panagiotis Passas, Sotirios Natsiavas

COMPUTING BACKBONE CURVES FOR NONLINEAR OSCILLATORS WITH HIGHER ORDER POLYNOMIAL STIFFNESS TERMS

Ayman Nasir, Neil Sims, David Wagg

TOWARD A SYSTEMATIC CONSTRUCTION OF THE BASIS FOR NONLINEAR GEOMETRIC REDUCED ORDER MODELS

X.Q. Wang, Marc Mignolet

NONLINEAR VIBRATIONS OF AN ELASTIC PLATE ON A VISCOELASTIC FOUNDATION MODELLED BY THE FRACTIONAL DERIVATIVE STANDARD LINEAR SOLID MODEL

Marina V. Shitikova, Anastasiya I. Krusser

NONLINEAR HARDENING BEHAVIOR OF A HELMHOLTZ RESONATOR 369

Emmanuel Gourdon, Alireza Ture Savadkoohi, Claude-Henri Lamarque

EMPIRICAL EXPRESSION PREDICTING SEISMIC DISPLACEMENT OF SANDY SLOPES IN GREECE IN TERMS OF SOIL PROFILE TYPE USING NON-LINEAR DYNAMIC STICK-SLIP ANALYSIS

Loukas C. Katsenis, Constantine A. Stamatopoulos, Vassilis P. Panoskaltsis

SUPPRESSION OF CLASSICAL FLUTTER OSCILLATIONS IN BLADED WHEEL USING INNER DAMPING EFFECT .401 Ludek Pesek, Pavel Snabl, Ch. S. Prasad

THE THEORY OF BODY COLLISIONS IN ROLLING THROUGH GEOMETRY, KINEMATICS AND DYNAMICS OF BILLIARDS

Katica Hedrih

THE EFFECT OF BUILDING'S RESPONSE ON THE FRAGILITY OF FREESTANDING SYMMETRIC OR ASYMMETRIC CONTENTS

Spyridon Diamantopoulos, Michalis Fragiadakis

MS 3: DYNAMIC BUCKLING

PARAMETRIC INSTABILITY OF PULTRUDED FIBER-REINFORCED POLYMER COLUMNS UNDER AXIAL HARMONIC FORCING

Julio C. Coaquira, Daniel C.T. Cardoso, Paulo B. Gonçalves, Diego Orlando 
EFFECTS OF INITIAL GEOMETRICAL IMPERFECTIONS ON DYNAMIC STABILITY OF CIRCULAR CYLINDRICAL PANELS

Frederico Silva, Wanclaine Vaz, Paulo Gonçalves

MS 4: DYNAMICS OF COMPOSITE MATERIALS

ON THE WAVE DYNAMICS OF MICROSCALE BISTABLE TENSEGRITY STRUCTURES 482

Andrea Micheletti, Zacharias Vangelatos, Narinder Singh, Costas P Grigoropoulos, Fernando Fraternali

PIECEWISE CONSTRUCTION OF WAVE DISPERSION CURVES IN ELASTIC PERIODIC NETWORKS BY ASYMPTOTIC MULTI-SCALE APPROACH 489

Antoine Rallu, Claude Boutin, Stéphane Hans

DEVELOPMENT OF FREQUENCY CURVES FOR CROSS-LAMINATED TIMBER (CLT) FLOORS USING DYNAMIC STIFFNESS METHOD

Miroslav Marjanović, Verica Jugović, Marija Nefovska-Danilović

ANALYTICAL SOLUTIONS FOR THE FLEXURAL NATURAL VIBRATION OF THE COMPOSITE GIRDERS WITH CORRUGATED STEEL WEBS

Yunsheng Li, Chaoxing Liu, Qingnian Dai, Yanling Zhang

METAMATERIALS WITH FIBERS OF ELLIPTIC CROSS-SECTION

Guy Bonnet, Vincent Monchiet

A TWO MODE NON-UNIFORM APPROXIMATION FOR AN ELASTIC ASYMMETRIC SANDWICH 528

Mohammed Alkinidri, Julius Kaplunov, Ludmila Prikazchikova

MODELING OF CFRP STRUCTURES USING MODEL UPDATING TECHNIQUES AND EXPERIMENTAL MEASUREMENTS

Ilias Zacharakis, Dimitrios Giagopoulos, loannis Zyganitidis, Alexandros Arailopoulos, Olga Markogiannaki

VIBRATION ANALYSIS OF LAMINATED COMPOSITE CYLINDRICAL SHELLS WITH VARIOUS FIBRE ORIENTATIONS ... 551 Chendi Zhu, Baiyang Shi, Chen Zhou, Jian Yang

ACOUSTIC WAVES IN HOMOGENIZED FLUID-SATURATED DEFORMING PERIODIC SCAFFOLDS UNDER PERMANENT FLOW

Eduard Rohan, Robert Cimrman, Salah Naili

A NEW ANALYTICAL METHOD FOR FREE VIBRATION ANALYSIS OF SANDWICH BEAMS 578

Lhoucine Boutahar, Zakaria Ibnorachid, Khalid El Bikri

HOMOGENIZED MODEL OF UNCONVENTIONAL DYNAMIC BEHAVIOUR OF PERIODIC PLATES AND

EXPERIMENTAL COMPARISONS 589

Pascal Fossat, Claude Boutin, Mohamed Ichchou 
L. Placidi, A. Amendola, M. Miniaci, F. Fraternali

INDUCING DISPERSION CURVES WITH NEGATIVE GROUP VELOCITY IN INERTIALLY AMPLIFIED PHONONIC CRYSTALS THROUGH THE APPLICATION OF AN EXTERNAL STATE OF PRESTRESS

M. Miniaci, M. Mazzotti, A. Amendola, F. Fraternali

\section{MS 5: DYNAMIC FLUID-STRUCTURE INTERACTION}

SUSCEPTIBILITY OF U-PROFILES WITH DIFFERENT GEOMETRY AND POROSITY TO GALLOPING

Stanislav Hračov, Michael Macháček

THE EFFECT OF FOLDING WINGTIPS ON THE FLIGHT DYNAMICS OF AN AIRCRAFT WITH ELASTIC WING

Davide Balatti, Hamed Haddad Khodaparast, Michael Friswell, Marinos Manolesos, Mohammadreza

Amoozgar

NONLINEAR STRUCTURAL BEHAVIOUR OF AN ARCH DAM UNDER STATIC AND DYNAMIC LOADS

Carla Ferreira, Helena Barros

A NEW OPEN SOURCE SOLVER FOR MODELLING FLUID-STRUCTURE INTERACTION: CASE STUDY OF A POINTABSORBER WAVE ENERGY CONVERTER WITH POWER TAKE-OFF UNIT

Bonaventura Tagliafierro, Rosario Montuori, loannis Vayas, Pablo Ropero, Alejandro Crespo, Jose Domınguez, Corrado Altomare, Giacomo Viccione, Moncho Gomez Gesteira

\section{MS 6: VEHICLE DYNAMICS}

SPEED DISTRIBUTION ON ROAD TEST SECTIONS FOR THE NEED OF PROFILE GROUND TESTING OF SPECIAL WHEELED VEHICLES

Mariusz Kosobudzki

TMEASY 6.0-A HANDLING TIRE MODEL THAT INCORPORATES THE FIRST TWO BELT EIGENMODES 676 Georg Rill

OPTIMIZATION OF NONLINEAR QUARTER CAR SUSPENSION-DRIVER SEAT MODEL USING GA BASED PID CONTROLLER

Omar El-Mezayen, Mustafa Qasem, Hesham Ibrahim, Nora Merabet, Zakaria.Elnaggar

ENHANCING ROAD - VEHICLE BEHAVIOR BY IMPLEMENTING ACTIVE - CONTROLLED DRIVER SEAT COMBINED WITH SEMI-ACTIVE GROUND HOOK SUSPENSION SYSTEM

Mohamed Ezzat, Hesham Ibrahim, Zakaria Elnaggar, Nora Merabet, Mohamed Salama

AUTO-SAPIENS, AN EXPERIMENTAL AUTONOMOUS DRIVING SYSTEM 718

Maicol Laurenza, Gianluca Pepe, Antonio Carcaterra 
IDENTIFICATION OF NONLINEAR ROAD-VEHICLE DYNAMIC BEHAVIOR USING AUTOREGRESSIVE TECHNIQUE ....734

Mohab Anwar, Mostafa Tamer, Mohamed Tawfik, Hesham Ibrahim

EFFICIENT METHODS TO ASSESS LINEAR AND NON-LINEAR AUTOMOTIVE PLATOON CONTROL STABILITY

AND PERFORMANCE

Christian Kalteis, Sebastian Thormann, Alexander Schirrer, Stefan Jakubek

ANALYSIS OF AUTOMOBILE BRAKE CREEP GROAN VIBRATIONS: TEST RIG EXPERIMENTS IN COMPARISON TO FINITE ELEMENT SIMULATIONS 758

Manuel Pürscher, Severin Huemer-Kals, Peter Fischer

\section{MS 7: SYSTEM IDENTIFICATION AND DAMAGE DETECTION}

VIBRATIONS FOR ESTIMATING BOLTED JOINT INTEGRITY (VEBJI) PROJECT: CHALLENGES AND RESULTS 785

Dmitri Tcherniak, Jon Juel Thomsen, Marie Brøns

NONPARAMETRIC NONLINEAR RESTORING FORCE AND EXCITATION IDENTIFICATION WITH LEGENDRE POLYNOMIAL AND DATA FUSION

Bin $\mathrm{Xu}$, Ye Zhao, Baichuan Deng

REDUCTION OF QUANTIZATION AND CLIPPING ERRORS USING BAYESIAN VIRTUAL SENSORS 808 Jyrki Kullaa

VIBRATION-BASED DAMAGE LOCALIZATION WITH DENSITY RATIO ESTIMATION METHOD

Yulong Zhang, John Macdonald, Paul Harper, Song Liu

PARAMETRIC SPECTRAL ESTIMATION AND DYNAMICS IDENTIFICATION FOR TRAVELING SURFACE VEHICLES ....833

Ilias A. Iliopoulos, Spilios D. Fassois, John S. Sakellariou

SYSTEM IDENTIFICATION AND DAMAGE DETECTION FRAMEWORK USING SIMULATING EXPERIMENTS AND MACHINE LEARNING TECHNIQUES

Panagiotis Seventekidis, Dimitrios Giagopoulos, Alexandros Arailopoulos, Olga Markogiannaki

AN IN-SITU EXPERIMENTAL SETUP FOR DAMAGE LOCALIZATION AND MECHANICAL PARAMETER ESTIMATION

Max Vollmering, Ivan Dolbonosov, Armin Lenzen

SUB-WAVELENGTH DAMAGE DETECTABILITY ASSESSMENT IN PERIODIC ASSEMBLIES USING A BLOCH MODELLING FRAMEWORK

Christophe Droz, Regis Boukadia, Elke Deckers, Wim Desmet

IDENTIFICATION OF DAMAGE TO A TWO-STORY HISTORIC MASONRY BUILDING IN NEPAL DUE TO THE 2015 GORKHA EARTHQUAKE USING NATURAL FREQUENCIES AND MODE SHAPES 
LIE SYMMETRIES, OBSERVABILITY AND MODEL TRANSFORMATION OF NONLINEAR SYSTEMS WITH UNKNOWN INPUTS

Xiaodong Shi, Manolis Chatzis

VIBRATION TESTING BASED ON EVOLUTIONARY OPTIMIZATION TO IDENTIFY STRUCTURAL FAILURES AND DAMAGE IN GLULAM COMPONENTS

Juan Peña-Lasso, Rebeca Sanchez-Ruiz, Alvaro Gaute, Ignacio Lombillo, Ramon Sancibrian, Oscar Ramon Ramos

A METHODOLOGY ON INTERPRETABLE NOVELTY DETECTION

Artur Movsessian, David Garcia Cava, Dmitri Tcherniak, R. Janeliukstis

INVESTIGATION ON DAMAGE SENSITIVE FEATURES FOR OPTIMAL SENSOR NETWORKS BASED ON REALSCALE RECORDINGS

Said Quqa, Michelangelo Malatesta, Panagiotis Martakis, Artur Movsessian

EXPERIMENTAL ASSESSMENT OF VIBRATION-BASED METHODS FOR DAMAGE LOCALIZATION 948

Michal Venglár, Pier Francesco Giordano, Maria Pina Limongelli, Milan Sokol

ON THE PROBLEM OF ON-BOARD VIBRATION-BASED FAULT DETECTION IN RAILWAY SUSPENSIONS UNDER VARYING OPERATING CONDITIONS: A FEASIBILITY STUDY

Georgios Vlachospyros, Nikolaos Kaliorakis, Ilias A. Iliopoulos, Spilios D. Fassois, John S. Sakellariou,

Alexandros Deloukas, George Leoutsakos, Ilias Chronopoulos, Christos Mamaloukakis

SYSTEM IDENTIFICATION OF CODE CONFORMING LOW-RISE RC BUILDING IN LALITPUR, NEPAL

Rajan Dhakal, Rajesh Rupakhety, Dipendra Gautam, Said Elias Rahimi

A DISPERSION-BASED METHODOLOGY FOR THE IN SITU ASSESSMENT OF BENDING STIFFNESS IN BRIDGE CABLES

João Rodrigues, Elsa Caetano, João Santos

A PSEUDO-INVERSE APPROACH TO THE PHYSICAL MODEL ESTIMATION PROBLEM. CAPACITIES AND LIMITATIONS

Alvaro Magdaleno, Jose M. Soria, Antolin Lorenzana

MODAL IDENTIFICATION OF STRUCTURES DURING STATIC LOAD TESTING: INTERACTION EFFECTS 1002

Antolin Lorenzana, Alvaro Magdaleno, Tomislav Jarak, Roberto Martinez, Antonio Balmori, Luis-Alfonso Basterra, Lara del Val, Juan J. Villacorta, Alberto Izquierdo

AN INTEGRATED VIBRATION-IMAGE PROCEDURE FOR DAMAGE IDENTIFICATION IN STEEL TRUSSES 1011

Marianna Crognale, Vincenzo Gattulli, Salvador Ivorra, Francesco Potenza

MAXIMUM LIKELIHOOD ESTIMATION OF DAMPING IN THE FREQUENCY DOMAIN DECOMPOSITION METHOD 1027

Javier Cara 
A NUMERICAL INVESTIGATION OF NEW ALGORITHMS FOR THE DRIVE-BY METHOD IN RAILWAY BRIDGE MONITORING

Lorenzo Bernardini, Marco Carnevale, Claudio Somaschini, K. Matsuoka, Andrea Collina

DAMAGE FEATURE RECOGNITION BASED ON LAMB WAVES DETECTION 1044

Xiaohui Wang, Jinhui Liang, Bin Zhang, Yeping Xiong, Jun Gao

\section{MS 8: STRUCTURAL HEALTH MONITORING}

DAMAGE ANALYSIS OF STEEL-CONCRETE COMPOSITE BEAMS UNDER STATIC LOADS 1053

Faraz Sadeghi, Xinqun Zhu, Jianchun $L i$

SEISMIC STRUCTURAL HEALTH MONITORING FOR REDUCING LIFE CYCLE COST OF ROAD BRIDGES 1063

Michela Torti, Ilaria Venanzi, Filippo Ubertini

ENGINEERED MODEL FOR THE NUMERICAL INVESTIGATION INTO VIBRATION CHARACTERISTICS OF A NOVEL BRIDGE BEARING UNDER FREE-FREE AND FIXED BOUNDARY CONDITION 1075

Pasakorn Sengsri, Charalampos Baniotopoulos, Sakdirat Kaewunruen

VIBRATION-BASED ROBUST DAMAGE DETECTION UNDER ASSEMBLY-INDUCED UNCERTAINTY: THE OUTPUT-ONLY CASE 1084

Andreas Mastakouris, Georgia Andriosopoulou, Kyriakos Vamvoudakis-Stefanou, Spilios Fassois

AUTOMATED OPERATIONAL MODAL ANALYSIS OF A STEEL ARCH BRIDGE FROM DYNAMIC SUBMICROSTRAIN FIBER BRAGG GRATING DATA 1096

Dimitrios Anastasopoulos, Guido De Roeck, Edwin P.B. Reynders

AN ITERATIVE MULTILEVEL UPDATING SCHEME FOR VIBRATION-BASED DAMAGE ASSESSMENT OF A PRESTRESSED CONCRETE GIRDER BRIDGE 1109

Leqia He, Edwin Reynders, Changgen Deng, Giuseppe C. Marano, Bruno Briseghella, Guido DeRoeck

AN LTE-M OPENTHREAD MESH NETWORK FOR DISTRIBUTED REAL-TIME STRUCTURAL HEALTH MONITORING OF CRITICAL INFRASTRUCTURE IN CANADA

Jason Thornton, Georgios Balomenos

DRIVE-BY RESONANT BRIDGE DETECTION METHOD USING TWO TRACK IRREGULARITIES MEASURED ON THE FIRST AND LAST VEHICLES OF A TRAIN

Kodai Matsuoka, Hirofumi Tanaka, Kyohei Kawasaki, Kazuhiro Kajihara

CHARACTERIZATION OF VIBRATIONS MEASURED IN THE GRONINGEN BUILDING MONITORING NETWORK .... 1147 Chris Geurts, Okke Bronkhorst, Davide Moretti, Jitse Pruiksma, Ron Snijders

MONITORING FATIGUE DAMAGE ACCUMULATION OF WIND TURBINE TOWERS USING LIMITED NUMBER OF OUTPUT-ONLY VIBRATION MEASUREMENTS

Victor Flores Terrazas, Omid Sedehi, Lambros S. Katafygiotis, Costas Papadimitriou 
DYNAMIC CHARACTERISTICS OF A SIX-STOREY STEEL BUILDING EXAMINED FROM STRONG MOTION AND AMBIENT VIBRATION DATA

Toshihide Kashima, Hiroto Nakagawa

REDUCTION OF TEMPERATURE EFFECTS FOR BRIDGE HEALTH MONITORING

Viet Ha Nguyen, Tanja Kebig, Jean-Claude Golinval, Stefan Maas

DISCUSSIONS ON ILL-POSED PROBLEM IN DRIVE-BY PAVEMENT ROUGHNESS IDENTIFICATION

Soichiro Hasegawa, Chul-Woo Kim, K. C. Chang, Naoya Toshi

DAMAGED DETECTION OF A BELL TOWER THROUGH OMA

Simone Castelli, Andrea Belleri, Alessandra Marini, Babak Moaveni

TOWARDS STRUCTURAL HEALTH MONITORING BASED RISK BASED INSPECTION PLANNING FOR OFFSHORE WIND TURBINE SUPPORT STRUCTURES

Simon Tewolde, Ruediger Höffer, Inka Mueller

INVESTIGATION OF EFFICIENT MODAL IDENTIFICATION OF BRIDGES USING BAYESIAN INFERENCE

Yoshinao Goi, Chul-Woo Kim

VIBRATION-BASED STRUCTURAL HEALTH MONITORING OF A REINFORCED CONCRETE BEAM SUBJECT TO VARYING AMBIENT TEMPERATURES USING BAYESIAN METHODS

Patrick Simon, Ronald Schneider, E. Viefhues, S. Said, Ralf Herrmann, Matthias Baeßler

MONITORING MONOPILE PENETRATION THROUGH MAGNETIC STRAY FIELD MEASUREMENTS

Peter Meijers, Apostolos Tsouvalas, Andrei Metrikine

MITIGATION OF ENVIRONMENTAL VARIABILITIES IN DAMAGE DETECTION: A COMPARATIVE STUDY OF TWO SEMI-SUPERVISED APPROACHES

Artur Movsessian, Bilal Ali Qadri, Dmitri Tcherniak, David Garcia Cava, Martin Dalgaard Ulriksen

IMPLEMENTING A STRUCTURAL HEALTH MONITORING SYSTEM USING DIGITAL MODELS OF THE BAM LARGE DROP TEST FACILITY IN HORSTWALDE

Ralf Herrmann, Falk Hille, S. Said, Jens Sterthaus, Karsten Müller, Thomas Quercetti, Frank Wille, J.-A.

Paffenholz, Matthias Baeßler

APPLICATION OF A CLASSIFICATION ALGORITHM TO THE EARLY-STAGE DAMAGE DETECTION OF A MASONRY ARCH

Alberto Barontini, Maria Giovanna Masciotta, Paulo Amado Mendes, Luís Ramos, Paulo Lourenço

VIBRATION-BASED DAMAGE DETECTION APPLIED TO A CONCRETE ARCH-DAM

Sérgio Pereira, Filipe Magalhães, Álvaro Cunha, Jorge Gomes, José Lemos

A FULLY AUTOMATED OMA PROCEDURE WITH ADAPTIVE TRACKING OF LONG-TERM MONITORING DATA: AN APPLICATION TO MASONRY TOWERS

Giacomo Zini, Michele Betti, Gianni Bartoli

VIBRATION-BASED ANOMALY DETECTION USING SPARSE AUTO-ENCODER AND CONTROL CHARTS 1335

Rafaelle Finotti, Carmelo Gentile, Flávio Barbosa, Alexandre Cury 
DESIGN OF A MONITORING SYSTEM FOR A LONG-SPAN SUSPENSION BRIDGE: OPTIMAL SENSOR PLACEMENT

Øyvind Wiig Petersen, Ole Øiseth, Gunnstein Thomas Frøseth

COMPARISON OF ALTERNATIVE DYNAMIC VIBRATION MITIGATION APPROACHES FOR WIND TURBINE TOWERS 1358

Konstantinos A. Kapasakalis, Pyros-Orfeas N. Bollano, Evangelos J. Sapountzakis, loannis A. Antoniadis

AN INTEGRATED MONITORING STRATEGY FOR CURRENT CONDITION ASSESSMENT OF HISTORIC BRIDGES .... 1373 Gabriele Ravizza, Rosalba Ferrari, Egidio Rizzi, Vasillis Dertimanis, Eleni Chatzi

APPLICATION OF WAVELET SYNCHRO-SQUEEZED TRANSFORM (WSST) METHOD TO RAILWAY BRIDGE HEALTH MONITORING 1388

Neda Mostafa, Richard Loendersloot, Dario Di Maio, Tiedo Tinga

DETECTION OF CLAMPING FORCE LOSS IN BOLTED JOINTS OF RAIL SUPPORTS IN CONSIDERATION OF CHANGING AMBIENT TEMPERATURE 1397

Anna-Lena Dreisbach, Volkan Yokaribas, Gerhard Dietrich, Daniel Sahm, Daniel Pak, Claus-Peter Fritzen

MS 9: STRUCTURAL CONTROL

NUMERICAL PERFORMANCE EVALUATION OF A BI-DIRECTIONAL ROLLER SEISMIC ISOLATION BEARINGS 1408

Ricardo González, Nelson Ortiz-Cano, Andrés Nieto-Leal, Carlos Gaviria-Mendoza

CONTROL LAW AND ACTUATOR CAPACITY EFFECT ON THE DYNAMIC PERFORMANCE OF A HYBRID MASS DAMPER; THE CASE OF ROTTWEIL TOWER 1422

Lefteris Koutsoloukas, Nikolaos Nikitas, Petros Aristidou, Christian Meinhardt

DOUBLE TUNED MASS DAMPER INERTER FOR SEISMIC RESPONSE REDUCTION OF STRUCTURES 1433

Mahdi Abdeddaim, Salah Djerouni, Abdelhafid Ounis, Nassim Djedoui

OPTIMAL FEEDBACK CONTROL LAW FOR VISCOELASTIC MATERIALS WITH MEMORY EFFECTS 1445 Gianluca Pepe, Elena Paifelman, Antonio Carcaterra

OPTIMAL DAMPER DISTRIBUTIONS IN SHEAR FRAMES CONSIDERING SOIL CONDITIONS 1459

Ersin Aydin, Baki Ozturk, Osman Sivrikaya

A LOCAL ACTIVE NOISE CONTROL SYSTEM BASED ON A NONLINEAR SENSING TECHNIQUE FOR YACHT APPLICATIONS 1475

Dimitrios Mylonas, Alberto Erspamer, Andreas Paradisiois, Christos Yiakopoulos, loannis Antoniadis

TUNING STRATEGIES AND PLACEMENTS FOR DISTRIBUTED MULTIPLE TUNED MASS DAMPERS FOR WINDINDUCED VIBRATION CONTROL IN HIGH-RISE BUILDINGS 1491 Ahmed Abed, Oum El Khaiat Moustachi 
MS 10: ADVANCES ON INERTER-BASED STRUCTURAL VIBRATION CONTROL

OPTIMUM DESIGN OF A TUNED-INERTER-HYSTERETIC-DAMPER (TIHD) FOR BUILDING STRUCTURES SUBJECT TO EARTHQUAKE BASE EXCITATIONS 1501

Predaricka Deastra, David Wagg, Neil Sims

RESPONSE CONTROL OF BUILDINGS USING TMDI UNDER WIND AND EARTHQUAKES 1510 Said Elias, Rajesh Rupakhety, Simon Olafsson

SUPPRESSION OF VIBRATION TRANSMISSION BETWEEN OSCILLATORS COUPLED WITH AN INERTER-BASED JOINT .... 1521

Zhuang Dong, Jian Yang, Han Meng, Dimitrios Chronopoulos

SEISMIC PROTECTION OF MULTI-STOREY ROCKING STRUCTURES WITH INERTERS 1529 Rodrigo Thiers-Moggia, Christian Málaga-Chuquitaype

THE EFFECTS OF PARASITIC MASS ON THE PERFORMANCE OF INERTER-BASED DYNAMIC VIBRATION ABSORBERS 1545

Hakan Dogan, Neil Sims, David Wagg

VIBRATION CONTROL OF STEEL LIQUID STORAGE TANKS EQUIPPED WITH INERTER-BASED ISOLATION SYSTEMS 1556

Daniele Zahedin Labaf, Maurizio De Angelis, Daniele Pietrosanti

INERTER-BASED VIBRATION ABSORBERS FOR ROTATING WIND TURBINE BLADES 1568 Zili Zhang

MOTION CONTROL PERFORMANCE OF TUNED MASS DAMPER INERTER (TMDI) IN CONTINUOUS WHITENOISE EXCITED CANTILEVERED BEAMS WITH VARIOUS SHAPES 1576

Zixiao Wang, Agathoklis Giaralis

MS 11: BRIDGE DYNAMICS

EXPERIMENTAL STUDY OF RAILWAY BRIDGES OF SEVERAL STRUCTURAL TYPOLOGIES 1586

Pedro Galvín, Emma Moliner, Antonio Romero, María Dolores Martínez-Rodrigo

DYNAMIC RESPONSE OF CORRUGATED STEEL CULVERTS FOR RAILWAY LINES 1613

Andreas Andersson, Raid Karoumi

DYNAMIC SOIL-STRUCTURE INTERACTION IN RESONANT RAILWAY BRIDGES WITH INTEGRAL ABUTMENTS .... 1625 Abbas Zangeneh, Andreas Andersson, Costin Pacoste, Raid Karoumi

A NEW APPROACH TO MODELLING ROCKING MOTION OF POST-TENSIONED SEGMENTAL COLUMNS 1634 Ehsan Ahmadi, Mohammad Kashani 
STOCHASTIC DYNAMIC ANALYSIS OF HIGH-SPEED MAGLEV GUIDEWAY COUPLED SYSTEM CONSIDERING VEHICLE PARAMETER

Peng Zhang, Zhi-wu Yu, Jian-feng Mao

RAIL-BRIDGE INTERACTION EFFECTS IN SINGLE-TRACK MULTI-SPAN BRIDGES. EXPERIMENTAL RESULTS VERSUS NUMERICAL PREDICTIONS UNDER OPERATING CONDITIONS

María D. Martínez-Rodrigo, Pedro Galvín, Emmanuela Moliner, Antonio Romero

VERTICAL COUPLING EFFECT OF THE BALLASTED TRACK ON THE DYNAMIC BEHAVIOR OF MULTITRACK RAILWAY BRIDGES COMPOSED BY ADJACENT DECKS 1666

Emmanuela Moliner, Antonio Romero, J.C. Sanchez-Quesada, María Dolores Martínez-Rodrigo,

Pedro Galvín

DISPLACEMENT BASED ANALYSIS AND DESIGN OF ROCKING BRIDGES 1680

Michalis F. Vassiliou, Natalia Reggiani Manzo

SEISMIC PERFORMANCE OF BRIDGES ISOLATED WITH DCFP DEVICES 1704

Paolo Castaldo, Guglielmo Amendola, Diego Gino, Elena Miceli

MEASUREMENTS OF AMBIENT VIBRATIONS FOR A CABLE-STAYED BRIDGE INCLUDING THE SOILFOUNDATION SYSTEM

Vanni Nicoletti, Davide Arezzo, Sandro Carbonari, Francesca Dezi, Fabrizio Gara

\section{MS 12: FOOTBRIDGE VIBRATIONS}

PERFORMANCE OF INERTIAL MASS CONTROLLERS FOR ULTRA-LIGHT FOOTBRIDGES: A CASE STUDY

Carlos M. C. Renedo, Iván M. Díaz, Justin M. Russel, Stana Živanović

INTERVAL SERVICEABILITY ASSESSMENT OF FOOTBRIDGES

Roberta Santoro, Alba Sofi, Federica Tubino

CLOSED-FORM SOLUTION OF THE RESPONSE OF SINGLE PEDESTRIAN INDUCED LOAD FOR CLAMPED-

CLAMPED BRIDGES

Daniel Colmenares, Andreas Andersson, Raid Karoumi

NUMERICAL VALIDATION OF THE GENERALISED EQUIVALENT SPECTRAL MODEL THROUGH CROWD DYNAMICS SIMULATIONS

Fiammetta Venuti, Federica Tubino

VALIDATION OF A NOVEL VIRTUAL REALITY PLATFORM FOR INVESTIGATING PEDESTRIAN-PEDESTRIAN INTERACTION IN THE CONTEXT OF STRUCTURAL VIBRATION SERVICE ABILITY

Artur Adam Soczawa-Stronczyk, Mateusz Bocian

MEASURING THE DYNAMIC RESPONSE OF A LIVELY FOOTBRIDGE TO AMBIENT AND WALKING EXCITATION ....1791 Alfredo Cigada, Carmelo Gentile, Giulia Lastrico, Maria Gabriella Mulas 
DYNAMIC PROPERTIES OF TWO PEDESTRIAN WOODEN BRIDGES INCLUDING SEASONAL EFFECTS 1805 John Hallak Neilson, Aida Ibisevic, Hasanhüseyin Ugur, Jean-Marc Battini, Roberto Crocetti, Costin Pacoste, Maria D. Martinez-Rodrigo

EVALUATION OF HUMAN INDUCED VIBRATIONS IN KJAERRA BRIDGE

Thomas Tenev, Ole Andre Kristiansen, Emrah Erduran

PERFORMANCE OF BIODYNAMIC MODELS TO REPRESENT THE ACTION OF A PEDESTRIAN IN THE VERTICAL DIRECTION

Rafaela Silva, Roberto Pimentel, Aleksandar Pavic

PEDESTRIAN LATERAL FOOT PLACEMENT AND LATERAL DYNAMIC INSTABILITY OF BRIDGES

Mateusz Bocian, Jeremy Burn, John Macdonald

MOTION-BASED DESIGN OF ACTIVE TUNED MASS DAMPERS TO CONTROL PEDESTRIAN-INDUCED VIBRATIONS IN FOOTBRIDGES UNDER UNCERTAINTY CONDITIONS

Javier Fernando Jiménez-Alonso, Jose Manuel Soria, Carlos Martín de la Concha Renedo, Francisco Guillen

González

CONTACT FORCE RECONSTRUCTION ON VIBRATING SURFACES 1854

Jeroen Van Hauwermeiren, Katrien Van Nimmen, B. Vanwanseele, Peter Van den Broeck

AN OPEN ACCESS BENCHMARK DATASET ON PEDESTRIAN-INDUCED VIBRATIONS COLLECTED ON THE EEKLO FOOTBRIDGE

Peter Van den Broeck, Jeroen Van Hauwermeiren, Katrien Van Nimmen

IDENTIFICATION OF HUMAN-STRUCTURE INTERACTION BASED ON FULL-SCALE OBSERVATIONS 1874

Katrien Van Nimmen, Jeroen Van Hauwermeiren, Peter Van den Broeck

A NOVEL METHOD FOR INDIRECT MEASUREMENT OF GROUND REACTION FORCES ON VIBRATING STRUCTURES

Andrei Firus, Roman Kemmler, Hagen Berthold, Steven Lorenzen, Jens Schneider

MS 13: HUMAN INDUCED VIBRATIONS IN FLOORS, STAIRCASES AND STADIA

SIMPLIFIED COMPUTATION OF TIMBER FLOOR VIBRATIONS LEVEL DUE TO HUMAN ACTIVITIES 1896

Thomas Catterou, Jean-Baptiste Castaing, Patrice Garcia

SYSTEM IDENTIFICATION OF HUMAN LEG SPRING STIFFNESS DURING RHYTHMIC JUMPING ON A PERCEPTIBLY MOVING SURFACE

Rory White, Nicholas Alexander, John Macdonald

ENVIRONMENTAL IMPACT OF STRUCTURAL MODIFICATIONS IN OFFICE FLOORS TO SATISFY VIBRATION SERVICEABILITY

Márcio S. Gonçalves, Aleksandar Pavic 
ANALYSIS THE LATERAL VIBRATION SERVICEABILITY OF TEMPORARY GRANDSTAND AND HUMAN COMFORT BASED ON EXPERIMENT 1932

Suhui Yu, Jian Yuan, Wei Wang, Chengqiang Gao, Weili Wang, Cong Liu

MS 14: WIND INDUCED VIBRATIONS OF SLENDER STRUCTURES AND FATIGUE

LARGE-SCALE AEROELASTIC TESTING TO INVESTIGATE THE RESILIENCY OF TRANSMISSION INFRASTRUCTURE TO HURRICANE STORMS 1944

Ziad Azzi, Amal Elawady, Arindam Chowdhury

A STUDY ON THE EVALUATION OF WIND INDUCED VIBRATION IN LONG-SPAN SUSPENSION BRIDGES WITH ARTIFICIAL NEURAL NETWORKS 1958

Dario Fernandez, Aksel Fenerci, Ole Øiseth

AUTHORIAL METHOD OF EVALUATING VIBRATIONAL COMFORT OF OCCUPANTS OF HIGH-RISE BUILDINGS BASED ON AEROELASTIC MODEL TESTS 1968

Aleksander Pistol, Łukasz Flaga, Piotr Krajewski, Andrzej Flaga

WIND TUNNEL TESTS ON MOTION-INDUCED VORTEX VIBRATION 1988 Kazutoshi Matsuda, Kusuo Kato, Nade Cao

DYNAMIC STUDY OF PORT CRANES SUBJECTED TO STOCHASTIC WIND ACTIONS 2001 Luigi Solazzi

ON THE VALIDATION AND USE OF A SIMPLIFIED MODEL OF AEOLIAN VIBRATION OF OVERHEAD LINES FOR PARAMETRIC STUDIES 2011

Emmanuel Cieren, John Redford, Maxime Guéguin, Olivier Allix, Christine Yang, Fikri Hafid, Jean-Michel Ghidaglia

FATIGUE LIFE ESTIMATION CONSIDERING THE QUASI-PERIODIC CROSS-WIND RESPONSE OF SLENDER STRUCTURES IN THE LOCK-IN RANGE

Francesca Lupi, Ruediger Höffer, Hans-Jürgen Niemann

MODELING THE INTERACTION OF GALLOPING AND VORTEX INDUCED VIBRATION FOR STEEL-CONCRETE COMPOSITE BRIDGES IN LAUNCHING PHASE 2040

Cong Chen, Niccolo Wieczorek, Julian Unglaub, Klaus Thiele

WIND TUNNEL VIV TESTING OF HELICAL STRAND CABLE MODELS 2054

Arsenii Trush, Stanislav Pospišil, Hrvoje Kozmar

NUMERICAL AND EXPERIMENTAL STUDY OF A SLENDER CATENARY BRIDGE WITH A NOVEL TENSIONING SYSTEM 2063

Gergely Szabó, Gábor Hochrein 
PREDICTION OF THE WIND-INDUCED FATIGUE OF SLENDER STRUCTURES

Michela Damele, Maria Pia Repetto

A STOCHASTIC AND CONTINUOUS MODEL OF AEOLIAN VIBRATIONS OF CONDUCTORS EQUIPPED WITH STOCKBRIDGE DAMPERS

Francesco Foti, Vincent Denoël, Luca Martinelli, Federico Perotti

ENHANCED SERVICE ABILITY PERFORMANCE IN WIND-EXCITED TALL BUILDINGS EQUIPPED WITH OPTIMAL TUNED MASS DAMPER INERTER VIA TOP-STOREY SOFTENING 2103

Zixiao Wang, Agathoklis Giaralis

\section{MS 15: DYNAMICS OF ON- AND OFF-SHORE WIND ENERGY STRUCTURES (WES)}

DYNAMICS OF TENSEGRITY SOLAR FAÇADES OPERATING AS MECHANICAL ENERGY HARVESTERS

Raffaele Miranda, Enrico Babilio, Narinder Singh, Diana P. Villamil, Filipe Santos, Fernando Fraternali

TALL OFFSHORE STEEL WIND TURBINE TOWERS UNDER WIND CURRENT AND WAVE LOADING: AN EXPERIMENTAL AND NUMERICAL STUDY

Yu Hu, Jian Yang, Charalampos Baniotopoulos, Xinger Wang, Xiaowei Deng

SPATIAL DISTRIBUTED CHARACTERISTICS OF DYNAMIC RESPONSE OF JACKET SUPPORTED OFFSHORE WIND TURBINES SUBJECTED TO HURRICANE INDUCED ENVIRONMENTAL LOADS

Bowen Jiang, Qingshan Yang, Guoqing Huang, Min Liu

SURROGATE MODEL FORMULATION FOR STOCHASTIC FLUTTER ANALYSIS OF WIND TURBINE BLADES UNDER UNCERTAIN AERODYNAMICS LOADS

Luca Caracoglia

A SYSTEMATIC INVESTIGATION OF COMMON GRADIENT BASED MODEL UPDATING APPROACHES APPLIED TO HIGH-FIDELITY TEST-DATA OF A WIND TURBINE ROTOR BLADE

Johannes Knebusch, Janto Gundlach, Yves Govers

PLATFORM OPTIMIZATION OF LARGE FLOATING OFFSHORE WIND ENERGY STRUCTURES

Giulio Ferri, Enzo Marino, Claudio Borri

DYNAMIC FIELD DATA FROM OFFSHORE MONOPILE WIND TURBINES - ASSESSMENT OF NATURAL

FREQUENCIES AND DAMPING

Karin Norén-Cosgriff, Amir M. Kaynia

MONITORING OF OFFSHORE WIND TURBINES UNDER WAVE AND WIND LOADING DURING INSTALLATION .... 2189

Aljoscha Sander, Christian Meinhardt, Klaus-Dieter Thoben

EXPERIMENTAL EVALUATION OF BENDING MOMENTS AT THE TOWER OF AN ONSHORE WIND TURBINE 2206 João Pacheco, Francisco Pimenta, Álvaro Cunha, Filipe Magalhães 
WIND TURBINE ROTOR BLADE VIBRATION - APPLICATION OF TWO ALTERNATIVE MODAL DECOMPOSITION

PROCEDURES

Evgueni Stanoev

\section{MS 16: VIBRATION-BASED ASSESSMENT AND SHM OF CULTURAL HERITAGE STRUCTURES}

STATISTICAL PROCESS CONTROL PROCEDURES FOR ONLINE DAMAGE DETECTION OF A MONUMENTAL MASONRY PALACE: THE CONSOLI PALACE IN GUBBIO, ITALY

Enrique García Macías, Filippo Ubertini

EFFECT OF NOISE IN THE TIME-FREQUENCY ESTIMATE OF THE PERIDYNAMIC BOND ELASTIC CONSTANT PARAMETER

Gaetano Miraglia, Rosario Ceravolo, G. Coletta

DYNAMIC MODELLING OF TRAM-INDUCED VIBRATION ON THE TEMPLE OF MINERVA MEDICA IN ROME 2266 Fernando Saitta, Sara Forliti, Alessandro Colucci, Angelo Tatì, Ivan Roselli

ENHANCED CONTINUOUS DYNAMIC MONITORING OF A COMPLEX MONUMENTAL PALACE THROUGH A LARGER SENSOR NETWORK

Alban Kita, Ilaria Venanzi, Nicola Cavalagli, Enrique Garcia-Macias, Filippo Ubertini

FE MODEL UPDATING OF MASONRY TOWERS: MODELING AND NUMERICAL ISSUES

Riccardo Mario Azzara, Maria Girardi, Cristina Padovani, Daniele Pellegrini, Leonardo Robol

INFLUENCE OF IMPORTANT STRUCTURAL STRENGTHENING ON THE DYNAMIC PROPERTIES OF A MASONRY ARCH BRIDGE

Chiara Pepi, Nicola Cavalagli, Massimiliano Gioffrè, Vittorio Gusella

A MULTIDISCIPLINARY APPROACH INTEGRATING GEOMATICS, DYNAMIC FIELD TESTING AND FINITE ELEMENT MODELING TO EVALUATE THE CONSERVATION STATE OF THE GUIMARÃES CASTLE'S TOWER KEEP

Luis Javier Sánchez-Aparicio, Maria Giovanna Masciotta, Daniele Pellegrini, Borja Conde, Maria Girardi, Cristina Padovani, Luis Ramos, Belén Riveiro

ENVIRONMENTAL EFFECTS ON THE DYNAMIC CHARACTERISTICS OF A HISTORIC CATHEDRAL 2323 Carmelo Gentile, Antonello Ruccolo

A DAMAGE LOCALISATION PROCEDURE FOR MASONRY TOWERS BASED ON FREQUENCY DATA 2338

Paolo Borlenghi, Carmelo Gentile, Antonella Saisi

MODAL PARAMETERS IDENTIFICATION ON ENVIRONMENTAL TESTS OF ANCIENT BELL TOWERS AND VALIDATION OF THEIR NUMERICAL MODELS

Francesco Clementi, Gianluca Standoli, Ersilia Giordano, Angela Ferrante, Stefano Lenci

MEASUREMENTS OF THE COLOSSEUM RESPONSE TO ENVIRONMENTAL ACTIONS 2367

Fabrizio Vestroni, Adriano De Sortis, Annamaria Pau 
ASSESSMENT OF THE TRM REINFORCEMENT OF WINDOWED MASONRY WALLS THROUGH OMA

IDENTIFICATION

Salvador Ivorra, Domenico Camassa, David Bru, Ignacio Gisbert, Anna Castellano, Aguinaldo Fraddosio, Mario Daniele Piccioni

MODAL IDENTIFICATION OF THE SAN FRANCESCO CHURCH IN PISA, ITALY

Emanuele Lorenzo, F. Canessa, Giuseppe Chellini, Anna De Falco, Carlo Resta, E. Savelli, Giacomo Sevieri

DYNAMIC ANALYSIS OF THE INTERACTION BETWEEN BELLS AND MASONRY STRUCTURES 2400

David Bru, Salvador Ivorra, Michele Betti, Gianni Bartoli, F. Javier, Baeza F. Borja Varona

MS 17: VIBRATIONS DUE TO CONSTRUCTION AND INDUSTRIAL ACTIVITIES

REDUCING IMPACT OF VIBRATIONS FROM COMPACTION ON SLOPE STABILITY 2407

Jörgen Johansson, Joonsang Park, Christian Madshus, Carl Wersäll 


\section{VOLUME II}

\section{Minisymposia}

MS 18: VIBRO-ACOUSTICS

A COUPLED MODELLING APPROACH FOR THE FAST COMPUTATION OF UNDERWATER NOISE RADIATION FROM OFFSHORE PILE DRIVING

Yaxi Peng, Apostolos Tsouvalas, Andrei Metrikine

WAVE-RESOLVING AIRCRAFT FUSELAGE MODEL FOR CABIN NOISE PREDICTIONS UNDER DISTRIBUTED FLUID LOADINGS

Christopher Blech, Sabine C. Langer

NUMERICAL EVALUATION OF THE SOUND TRANSMISSION OF A STRUCTURAL SYSTEM WITH ATTACHED NOISE CONTROL TREATMENTS USING STATISTICAL ENERGY ANALYSIS 2446 Thaynan Oliveira

BAND STRUCTURE OF ELASTIC BODIES WITH PERIODIC NONLOCALITIES

A. S. Rezaei, S. V. Sorokin, F. Mezzani, A. Carcaterra

GLOBAL LONG WAVE APPROXIMATIONS FOR ELASTIC WAVE GUIDES

Kirill Cherednichenko, Julius Kaplunov, Danila Prikazchikov, Leyla Sultanova

A NOVEL VIEW ON THE COMPOSITION OF ENERGY FLOW IN MULTI-MODAL WAVEGUIDES

Lasse S. Ledet, Sergey V. Sorokin

ACOUSTIC BLACK HOLE PROFILE OPTIMIZATION

Horia Cornean, Sergey Sorokin, Benjamin Støttrup

NOISE REDUCTION USING THE CONCEPT OF ACOUSTIC BLACK HOLES DESIGNED BASED ON MODAL ANALYSIS

Bjørnar Saurdal, Daniel Villadsen, Sergey Sorokin, Lasse Ledet

OPTIMIZATION OF PERFORMANCE OF WAVEGUIDES USING THE WAVE FINITE ELEMENT METHOD

Peter Broberg, Mikkel Steffensen, Sergey Sorokin, Lasse Ledet

FAST FREQUENCY SWEEPS FOR UNBOUNDED MEDIA: AN EFFICIENT PERFECTLY MATCHED LAYER FINITE ELEMENT FORMULATION 2508

Romain Rumpler, Antoine Vermeil de Conchard, Huina Mao

\section{MS 19: BLAST AND IMPACT LOADS}

IMPACT DAMAGE CHARACTERIZATION AT RC PLATES WITH PLANAR TOMOGRAPHY AND FEM 2521

Deborah Nerger, Robabeh Moosavi, Franz Bracklow, Marcus Hering, Tino Kühn, Manfred Curbach, Falk Hille, Andreas Rogge 
MODEL REDUCTION FOR STRUCTURES SUBJECTED TO BLAST LOADING BY USE OF DYNAMIC SUBSTRUCTURING

Linus Andersson, Peter Persson, Kent Persson

2DOF BLAST ANALYSIS OF BUILDINGS

Sander Meijers, Peter Flink, Harm Kraaijenbrink, Meindert Wiersma

PROTECTION OF MASONRY STRUCTURES AGAINST EXPLOSIONS APPLYING LAYERS OF TEXTILE REINFORCED MORTAR

Leonidas Alexandros Kouris, Georgios Valsamos, Savvas Triantafyllou, Vasileios Karlos, Daniel A. Pohoryles, Dionysios A. Bournas, Martin Larcher, Folco Casadei

\section{MS 20: MOVING LOADS}

SIMPLIFIED DYNAMIC RESPONSE ANALYSIS OF A RAILWAY BRIDGE CONSIDERING SOIL-STRUCTURE INTERACTION

Christoph Adam, Benjamin Hirzinger

DYNAMIC AMPLIFICATION FACTORS FOR ULTRA-HIGH-SPEED HYPERLOOP TRAINS: VERTICAL AND LATERAL VIBRATIONS

Ehsan Ahmadi, Mohammad Kashani, Nicholas Alexander

MOVING LOAD ON AN ELASTIC HALF-SPACE COATED WITH A THIN VERTICALLY INHOMOGENEOUS LAYER 2601 Saad Althobaiti, Vladimir Bratov, Ali Mubaraki, Danila Prikazchikov

VERIFICATION OF THE VALIDITY OF THE IMPACT FACTOR USED IN THE DESIGN OF PC SLEEPERS 2612

Shintaro Minoura, Tsutomu Watanabe, Kodai Matsuoka, Kenji Narita

DYNAMIC RESPONSE OF SINGLE AND MULTI-SPAN BEAMS UNDER A MOVING LOAD USING DYNAMIC STIFFNESS FORMULATIONS AND GALERKIN'S METHOD 2621

Baran Bozyigit, Sinan Acikgoz, Yusuf Yesilce

THE IN-PLANE STEADY-STATE RESPONSE OF A RING IN RELATIVE MOTION TO A CONSTANT LOAD

Tao Lu, Apostolos Tsouvalas, Andrei Metrikine

TRAIN-WEIGHT-IN-MOTION IDENTIFICATION MEASURING TIME-HISTORIES OF RAIL STRAINS 2638

Annamaria Pau, Fabrizio Vestroni

DYNAMIC EFFECT OF TRAINS WITH ARTICULATED COACHES AND JACOBS BOGIES WITH INTEGER WHEELBASE RATIOS 2646

Pedro Museros, Andreas Andersson, Raid Karoumi

ANALYSIS OF VIBRATIONS INDUCED BY PROXIMATE MASSES TRAVERSING A BEAM SUPPORTED BY A FINITE DEPTH FOUNDATION WITH PARTIAL SHEAR RESISTANCE 2658

Zuzana Dimitrovová 


\section{MS 21: TRAFFIC INDUCED VIBRATIONS}

REDUCING VIBRATIONAL IMPACT LATERAL OF A RAILWAY TRACK ON AN URBAN DEVELOPMENT PROJECT ..... 2680 Felix Mertens, Thomas Jaquet

IMPROVED FLOATING SLAB TRACK PERFORMANCE BY ON TOP INSTALLED TUNED MASS DAMPER 2688

Thomas Jaquet, Wang Bo

A MIXED-FRAME-OF-REFERENCE MODEL FOR RAILWAY INDUCED SOIL-STRUCTURE VIBRATION INTERACTION

Paulius Bucinskas, Evangelos Ntotsios, David Thompson, Lars Andersen

THE USE OF MULTIPLE MODELS TO ANALYSE RAILWAY TRACK GROUND DYNAMICS

Panudech Chumyen, David Connolly, Kaitai Dong, Pedro Costa, Paulo Soares, Peter Woodward

OURS - INTRODUCING THE DUTCH FORMAL MODEL FOR RAILWAY VIBRATION

Arnold Koopman

SUBSOIL MODELLING FOR RAILWAY INDUCED VIBRATIONS

Bruno Zuada Coelho, Sven Lentzen, Maarten Pronk, Dirk de Lange, Eleni Smyrniou, Marc Hijma

NUMERICAL ASSESSMENT OF THE INFLUENCE OF BALLAST HETEROGENEITIES ON THE DYNAMIC BEHAVIOR OF RAILWAY TRACKS

Hadrien Pinault, Etienne Balmes, Elodie Arlaud, Régis Cottereau

MITIGATION OF VIBRATION INDUCED BY RAILWAY TRAFFIC USING GRANULAR BARRIERS

Patryk Dec, Régis Cottereau, Baldrik Faure

\section{MS 22: DYNAMIC SOIL-STRUCTURE INTERACTION AND WAVE PROPAGATION}

SCATTERING OF ELASTIC WAVES BY TRANSVERSELY ISOTROPIC SPHERE

Ata Jafarzadeh, Peter D. Folkow, Anders Boström

A 2.5D FEM-BEM-MFS METHODOLOGY FOR SOIL-STRUCTURE INTERACTION PROBLEMS IN LAYERED HALF-SPACES

Hassan Liravi, Robert Arcos, Dhananjay Ghangale, Jordi Romeu

A NEW SEMI-ANALYTICAL APPROACH FOR DYNAMIC PILE-SOIL INTERACTION PROBLEM 2807 Kenny Conto, Robert Arcos, Cecília Parente, Pedro Alves Costa, Jordi Romeu 
STRUCTURE-SOIL-STRUCTURE INTERACTION ANALYSIS FOR REINFORCED CONCRETE FRAMED STRUCTURES .... 2817 Reine Fares, Maria Paola Santisi d'Avila, Anne Deschamps, Evelyne Foerster

COUPLED ITM-FEM APPROACH FOR THE ASSESSMENT OF THE MITIGATION EFFICIENCY OF FINITE AND INFINITE OPEN TRENCHES AND SOFT FILLED BARRIERS

Julian Freisinger, Gerhard Müller

SOIL-STRUCTURE INTERACTION OF AN END-BEARING PILE FOUNDATION: DESIGN OF AN EXPERIMENTAL

CASE STUDY

Freddie Theland, Jean-Marc Battini, Costin Pacoste, Geert Lombaert, Stijn François, Peter Blom, Fanny

Deckner

VIBRATIONS OF RECTANGULAR FLEXIBLE FOUNDATION ON HALFSPACE

Marko Radišić, Mira Petronijević, Gerhard Müller

THE EFFECTS OF MODEL ASSUMPTIONS ON THE DYNAMIC IMPEDANCE FUNCTIONS OF A SHALLOW FOUNDATION

Johan Lind Östlund, Andreas Andersson, Mahir Ülker-Kaustell, Jean-Marc Battini

ANALYSIS OF SEISMIC METASURFACES USING SPECIALISED ASYMPTOTIC MODELS FOR RAYLEIGH WAVES 2882

Peter Wootton, Julius Kaplunov, Danila Prikazchikov

INCREMENTAL DYNAMIC ANALYSES OF BRIDGE PYLONS WITH CONSIDERATION OF THE EFFECT OF SURFACE WAVES

Charisis Chatzigogos, Kristel Meza Fajardo

TRANSIENT ANALYSIS IN HALF-SPACE COMBINING IGA AND THE PERFECTLY MATCHED LAYER METHOD 2909

Arturo Méndez Salas, Margarita Chasapi, Sven Klinkel

NUMERICAL WAVENUMBER INTEGRATION FOR 2.5D WAVE EQUATION SOLUTION

Joonsang Park, Karin Norén-Cosgriff, Amir M. Kaynia

USE OF THE DOMAIN REDUCTION METHOD TO SIMULATE THE SEISMIC RESPONSE OF AN EXISTING STRUCTURE PROTECTED BY RESONATING UNIT CELL METAMATERIALS

Constantinos Kanellopoulos, Boris Jeremić, loannis Anastasopoulos, Božidar Stojadinović

THE EFFECT OF SOIL LIQUEFACTION ON THE SEISMIC PERFORMANCE OF A TYPICAL PORT QUAY WALL

Stella Karafagka, Stavroula Fotopoulou, Anna Karatzetzou, Georgia Kroupi, Kyriazis Pitilakis

A 2.5 DIMENSIONAL INDIRECT TREFFTZ METHOD TO MODEL LINEAR ELASTIC SOILS

Hannes Englert, Fei Qu, Gerhard Müller

MITIGATION OF GROUND VIBRATION FROM PILE DRIVING BY CIRCULAR ARRAYS OF RIGID BLOCKS

PLACED ON THE GROUND SURFACE

Lars Vabbersgaard Andersen, Peter Persson, Andrew T. Peplow

TIME DOMAIN BEM-FEM COUPLING FOR SEISMIC SOIL-STRUCTURE INTERACTION ANALYSES CONCEIVED FOR AN ANSYS-MATLAB WORKFLOW

Francesca Taddei, Bettina Chocholaty, Gerhard Müller 
EXPERIMENTAL IDENTIFICATION OF THE DYNAMIC BEHAVIOUR OF PILE-SOIL SYSTEM INSTALLED BY MEANS OF THREE DIFFERENT PILE-DRIVING TECHNIQUES

Athanasios Tsetas, Sergio S. Gomez, Apostolos Tsouvalas, Kees van Beek, Faraz S. Tehrani, Evangelos Kementzetzidis, Federico Pisano, Ahmed Elkadi, Maxim Segeren, Timo Molenkamp, Andrei V. Metrikine

DEVELOPMENT OF A METAMATERIAL PERIODIC FOUNDATION FOR SEISMIC PROTECTION 3016 Ahmad Saoud, Ahmad Omar, Diogo Queiros-Conde

GENERATION OF ARTIFICIAL ACCELEROGRAMS CONSISTENT WITH EARTHQUAKE-INDUCED GROUND MOTIONS 3027

Federica Genovese, Giuseppe Muscolino, Giovanni Biondi, Ernesto Cascone

MS 23: ASSESSMENT OF INDUSTRIAL STRUCTURES AND INFRASTRUCTURE UNDER NATURAL HAZARDS

FULL SCALE DYNAMIC TESTING OF WALL PANEL CONNECTIONS FOR PRECAST INDUSTRIAL BUILDINGS 3043

Ilaria Venanzi, Laura lerimonti, Filippo Ubertini, Annibale Luigi Materazzi, Leonardo Casali, Giuseppe Paci

GROUND MOTION MODEL FOR SEISMIC VULNERABILITY ASSESSMENT OF PROTOTYPE INDUSTRIAL

PLANTS 3053

Chiara Nardin, Rocco Di Filippo, Roberto Endrizzi, Igor Lanese, Fabrizio Paolacci, Oreste Salvatore Bursi

SIMPLIFIED ESTIMATION OF DESIGN FAULT DISPLACEMENT FOR BURIED PIPELINES AT FAULT CROSSING 3067

Vasileios Melissianos, Dimitrios Vamvatsikos

\section{MS 24: SEISMIC PROTECTION OF STEEL STRUCTURES BY MEANS OF DISSIPATIVE SYSTEMS AND COMPONENTS}

INNOVATIVE DISSIPATIVE DEVICES WITH TENSEGRITY ARCHITECTURE AND SUPER ELASTIC BEHAVIOUR FOR THE SEISMIC PROTECTION OF STRUCTURES 3079

Narinder Singh, Ada Amendola, Filipe Amarante Dos Santos, Gianmario Benzoni, Fernando Fraternali

EARTHQUAKE EFFECTS ON LOW PROFILE CONTAINER CRANE WITH SEISMIC ISOLATION DEVICE 3086 Luigi Solazzi

STEEL TRUSS BRIDGE WITH BUCKLING RESTRAINED DAMPER UNDER SEISMIC LOADING 3097 Purevdorj Sosorburam, Eiki Yamaguchi

MONOTONIC AND CYCLIC BEHAVIOUR OF THE BEAM-TOCOLUMN JOINTS OF THE "FUTURE" MOCKUP 3107 Roberto Tartaglia, Mario D'Aniello, Raffaele Landolfo

DAMAGE-AVOIDANCE STEEL ROCKING FRAMES WITH BUCKLING-ENABLED COMPOSITE BRACING 3117 Leena Tahir Kibriya, Christian Málaga-Chuquitaype, Mohammad Mehdi Kashani 
OPTIMIZATION OF DISSIPATIVE REPLACEABLE LINK FRAMES BY ELASTIC HIGH STRENGTH STEEL

COUPLING BEAMS

Marius Pinkawa, Cristian Vulcu, Benno Hoffmeister, Markus Feldmann

USE OF HIGH-STRENGTH STEEL FOR MULTI-CRITERIA OPTIMIZATION OF DISSIPATIVE DEVICES 3144

Silvia Caprili, Ivan Panzera, Walter Salvatore

ENHANCED STRUCTURAL RESILIENCE THROUGH THE USE OF “LEAF-SPRING” COLUMNS AND REPLACEABLE DISSIPATIVE COMPONENTS 3154

Cristian Vulcu, Marius Pinkawa, Aurel Stratan, Benno Hoffmeister

\section{MS 25: EXPERIMENTAL EARTHQUAKE ENGINEERING}

EXPERIMENTAL INVESTIGATION OF THE INFLUENCE OF TENSILE STRAIN ON THE CRACKING OF R/C VERTICAL STRUCTURAL ELEMENTS

Theodoros A. Chrysanidis, Vassilis P. Panoskaltsis

EVALUATION OF CRACKING BEHAVIOR OF R/C VERTICAL COMPONENTS REINFORCED WITH VARYING LONGITUDINAL REINFORCEMENT RATIOS

Theodoros A. Chrysanidis, Vassilis P. Panoskaltsis

GRAPHENE-RUBBER LAYERED COMPOSITES FOR SEISMIC ISOLATION

Maria Rosaria Marsico, Julián Mauricio Londoño Monsalve

CYCLIC PERFORMANCE OF WIND TURBINE TOWER WITH CONCRETE FILLED DOUBLE SKIN STEEL TUBES SECTION UNDER TORSION.

Yu-HangWang, Shu-Qi Wang, Guo-Bing Lu, Ji-Ke Tan

THE ST. SILVESTRO BELFRY IN L'AQUILA: FROM THE REHABILITATION WORKS TO THE ACTUAL PERFORMANCE IN TERMS OF DYNAMIC PROPERTIES AND FRAGILITY FUNCTIONS ESTIMATION 3218 Ilaria Capanna, Riccardo Cirella, Angelo Aloisio, Rocco Alaggio, Franco Di Fabio, Massimo Fragiacomo

OUT-OF-PLANE SHAKING TABLE TESTS ON DUTCH BUILDING PRODUCTS

Alexander Johannes Bronkhorst, C.P.W. Geurts

AN EXPERIMENTAL STUDY ON THE RELATIONSHIP BETWEEN EARTHQUAKE DAMAGE AND THE NATURAL FREQUENCY OF WOODEN HOUSE

Kazuhiro Hayashi, Ariyoshi Yamada, Yoshiyuki Komiya

PERFORMANCE OF A LINEAR SOLUTION FOR APPROXIMATING NONLINEAR RESPONSE OF REINFORCED CONCRETE STRUCTURES SUBJECTED TO EARTHQUAKE SHAKING

Kevin Kariuki, Tarjei Heen, Lars Halvor Kaasa, Amir Massoud Kaynia

BEHAVIOUR OF REINFORCED CONCRETE STRANDS DURING TENSION TEST INSPECTED WITH DIC 3261 Haukur Eiriksson, Bjarni Bessason 
Rita Abou-Jaoude, Nisrine Makhoul, Jean-Alain Fleurisson, Alexandrine Gesret

HYBRID COLLAPSE TEST OF STEEL COLUMNS WITH NONLINEAR FRAME SUBSTRUCTURING AND FORCE REDISTRIBUTION

Konstantinos Skalomenos, Masahiro Kurata, Yoshiki Ikeda

FRF-BASED MODAL TESTING OF HORIZONTALLY SWAYING STRUCTURES USING OCXO SYNCHRONISED WIRELESS ACCELERAMETERS FOR SIMULTANEOUS FORCE AND VIBRATION RESPONSE MEASUREMENTS 3301

Wai Kei Ao, Aleksandar Pavic

TESTING OF ADDITIVELY MANUFACTURED SMALL SCALE RC SPECIMENS FOR STATISTICAL VALIDATION OF STRUCTURAL MODELS IN EARTHQUAKE ENGINEERING

Lorenzo Del Giudice, Rafal Wrobel, Christian Leinenbach, Michalis F. Vassiliou

MEASUREMENT OF SOIL STRAINS UNDER EARTHQUAKE LOADING

Xiaoyu Guan, Gopal Madabhushi, Mark Talesnick

STRUCTURAL PROPERTIES OF UNREINFORCED MASONRY WALLS CONSIDERING CONSTRUCTION QUALITIES .... 3334 Dong-Hyeon Shin, Hyung-Joon Kim

DIRECT OBSERVATION OF BOND FAILURE OF FATIGUE PULLOUT TEST WITH LIQUID WATER BY USING DIC 3343 Ahmed Okeil, Koji Matsumoto, Kohei Nagai

SHAKE TABLE TEST FOR SEISMIC PERFORMANCE EVALUATION ACCORDING TO ANCHORING INTERVAL OF SUPPORT ELEMENTS PANEL SYSTEM 3355

Jaehan Park, Haeyong Park, Sanghoon Oh

SHAKING TABLE TEST FOR EVALUATION OF SEISMIC PERFORMANCE ACCORDING TO EDGE CLEARANCE OF GLAZING CURTAIN WALL SYSTEM

Jung Woo Yang, Hae Yong Park, Sang Hoon Oh

EXPERIMENTAL SEISMIC ASSESSMENT AND PROTECTION OF MUSEUM ARTEFACTS

M. Fragiadakis, L. DiSarno, A. Saetta, M. G. Castellano, I. Rocca, S. Diamantopoulos, V. Crozet,

I. Politopoulos, T. Chaudat, S. Vasic, I.E. Bal, E. Smyrou, I. Psycharis, T.C. Hutchinson, L. Berto

A MACHINE LEARNING APPROACH TO NONLINEAR RESPONSE ANALYSIS OF STRUCTURES

Panagiotis Georgakis, Manolis Georgioudakis, Michalis Fragiadakis

\section{MS 26: UQ AND PROBABILISTIC LEARNING IN COMPUTATIONAL DYNAMICS}

IDENTIFICATION OF A STOCHASTIC PROCESS MODELING THE STIFFNESS OF THE VOCAL FOLDS FOR A VOICE PRODUCTION MODEL REPRESENTED BY A NEURAL NETWORK 3403

Edson Cataldo, Christian Soize, R.L. Silva, João Marcos Silva 
STATE-OF-THE-ART REVIEW OF MACHINE LEARNING APPLICATIONS TO GEOTECHNICAL EARTHQUAKE ENGINEERING PROBLEMS

MS 27: STOCHASTIC DYNAMICS AND RELIABILITY ANALYSIS OF STRUCTURAL AND MECHANICAL SYSTEMS UNDER ENVIRONMENTAL EXCITATION

RELIABILITY ASSESSMENT OF THE DYNAMIC BEHAVIOR OF HIGH-SPEED RAILWAY BRIDGES USING FIRST ORDER RELIABILITY METHOD

Reza Allahvirdizadeh, Andreas Andersson, Raid Karoumi

RESPONSE OF ELASTIC SHOCK OSCILLATORS AND ELASTOPLASTIC OSCILLATORS, WHITELY EXCITED, FROM ENERGY BALANCE AND STOCHASTIC ANALYSES

Laurent Borsoi, Philippe Piteau

EFFICIENT ESTIMATION OF THE SKEWNESS OF THE RESPONSE OF A WAVE-EXCITED OSCILLATOR

Margaux Geuzaine, Vincent Denoël

EXTREME DYNAMIC RESPONSE OF EXTENDED BRIDGE STRUCTURES SUBJECTED TO INHOMOGENEOUS ENVIRONMENTAL LOADING

Bernt Leira, Jian Dai

UNCERTAINTY ABOUT ENVIRONMENTAL VIBRATION TESTS: A CASE STUDY

Alice Di Primio, Noemi Fiorini, Daniele Spina, Claudio Valente, Marcello Vasta

RESPONSE OF NONLINEAR SECONDARY OSCILLATORS IN CASCADE TO RANDOM EXCITATION 3507

Stavros Kasinos, Eleni Chatzi, Christian Málaga-Chuquitaype

MS 28: UNCERTAINTIES ON MATERIALS AND ENVIRONMENTAL LOADS

EFFECTS OF MECHANICAL UNCERTAINTIES ON DYNAMIC PROPERTIES OF CROSS-LAMINATED TIMBER FLOORS

Marija Milojević, Marija Nefovska-Danilović, Stana Živanović, Miroslav Marjanović

MODEL UNCERTAINTIES IN NLFEAS OF RC SYSTEMS UNDER CYCLIC LOADS

Paolo Castaldo, Diego Gino, Guglielmo Amendola, Elena Miceli

UNCERTAINTIES IN WIND-INDUCED LOADS ON HYPERBOLIC PARABOLOID ROOFS: WIND-TUNNEL TESTS AND ANALYTICAL MODELS

Fabio Rizzo, Vincenzo Sepe 
MS 29: BAYESIAN UPDATING, FILTERING AND INVERSION FOR DYNAMIC SYSTEMS

BAYESIAN MODEL UPDATING FOR EXISTING SEISMIC-ISOLATED BRIDGES USING OBSERVED ACCELERATION RESPONSE DATA

Masaru Kitahara, Matteo Broggi, Michael Beer

NONLINEAR SYSTEM IDENTIFICATION OF CORRODED REINFORCED CONCRETE STRUCTURES BASED ON SEISMIC RESPONSE DATA

Shaghayegh Abtahi, Zhenning Liu, Yong Li

DAMAGE DETECTION OF JOINING TECHNOLOGIES FOR PRINTED CONTROLLER BOARDS IN AUTOMOBILES ..... 3581 Moritz Hülsebrock, Maximilian Herrnberger, Heiko Atzrodt, Roland Lichtinger

REAL-TIME BAYESIAN PARAMETER, STATE AND INPUT ESTIMATION USING OUTPUT-ONLY VIBRATION MEASUREMENTS 3590

Daniz Teymouri, Omid Sedehi, Lambros S. Katafygiotis, Costas Papadimitriou

HIERARCHICAL BAYESIAN UNCERTAINTY QUANTIFICATION OF DYNAMICAL MODELS UTILIZING MODAL STATISTICAL INFORMATION 3599

Omid Sedehi, Costas Papadimitriou, Lambros Katafygiotis

MS 30: RECENT ADVANCES IN PERFORMANCE-BASED ENGINEERING AND DESIGN OF STRUCTURES AND CIVIL INFRASTRUCTURE SYSTEMS SUBJECTED TO SINGLE OR MULTIPLE HAZARDS

RISK-TARGETED MAPS FOR ALICANTE PROVINCE (SPAIN) 3607

Alireza Kharazian, Sergio Molina, Juan Jose Galiana-Merino, Noelia Agea-Medina

EFFECT OF MODELLING ASSUMPTIONS ON THE SEISMIC PERFORMANCE ASSESSMENT OF THIN REINFORCED CONCRETE WALL BUILDINGS 3618

Orlando Arroyo, Dirsa Feliciano, Julián Carrillo, José Colombo

SENSITIVITY OF SPECIAL STEEL MOMENT FRAMES TO THE INFLUENCE OF COLUMN-BASE HYSTERETIC BEHAVIOR INCLUDING GRAVITY FRAMING SYSTEM

Pablo Torres-Rodas, Francisco Flores, Bryam Astudillo, Sebastian Pozo

A MULTI-OBJECTIVE OPTIMAL PARAMETER DESIGN PROCEDURE FOR SLIDE BRIDGE BEARINGS UNDER SEISMIC EXCITATION BASED ON A DETERMINISTIC-STOCHASTIC MODELING APPROACH 3643

Xinhao He, Akira Igarashi

PARAMETRIC ANALYSIS AND COMPARISON OF MODELS USED IN THE ANALYSIS OF STEEL STRUCTURES 3655 Bryam Astudillo, Sebastian Pozo, Francisco Flores

DYNAMIC RESPONSE OF EXISTING STEEL FRAMES WITH MASONRY INFILLS UNDER MULTIPLE EARTHQUAKES 3671

Luigi Di Sarno, Jing-Ren Wu, Fernando Gutiérrez-Urzúa, Fabio Freddi, Mario D’Aniello, Ob-Sung Kwon, Stathis Bousias, Matjai Dol§ek 
Akrivi Chatzidaki, Konstantinos Bakalis, Dimitrios Vamvatsikos

LIMITATIONS OF EUROCODE 8 DUAL DUCTILITY CLASS APPROACH IN SEISMIC DESIGN OF RC HIGH-RISE BUILDINGS

Jelena Pejovic, Nina Serdar, Radenko Pejovic

SEISMIC PERFORMANCE AND RESILIENCE QUANTIFICATION OF A ROCKING BRIDGE FRAME 3709 Anastasios Giouvanidis, You Dong

MODIFIED INTENSITY MEASURES TO IMPROVE ACCURACY IN FRAGILITY ANALYSIS

Matteo Ciano, Massimiliano Gioffrè, Klaus Thiele, Mircea Grigoriu

OPTIMAL VISCOUS DAMPER PLACEMENT TO PREVENT POUNDING OF ADJACENT BUILDINGS

Huseyin Cetin, Baki Ozturk, Ersin Aydin

SEISMIC RELIABILITY-BASED DESIGN OF STRUCTURES EQUIPPED WITH DFPS

Paolo Castaldo, Gaetano Alfano

GLOBAL AND LOCAL PERFORMANCE LEVELS ON THE PROBABILISTIC EVALUATION OF THE STRUCTURAL POUNDING EFFECT BETWEEN ADJACENT RC STRUCTURES

Maria Flegga, Maria Favvata

FRAGILITY CURVES FOR RC FRAMED BUILDINGS SUBJECTED TO EARTHQUAKE-INDUCED LANDSLIDE:

COMPARISON BETWEEN 2D AND 3D STRUCTURAL MODELS

Giacomo Miluccio, Fulvio Parisi, Edoardo Cosenza

IMPACT OF CUMULATIVE DAMAGE ON FRAGILITY OF RC FRAMED BUILDINGS SUBJECTED TO EARTHQUAKE-INDUCED LANDSLIDES

Giacomo Miluccio, Fulvio Parisi, Edoardo Cosenza

\section{MS 31: EUROPEAN ETN “DYNAMIC VIRTUALISATION: MODELLING PERFORMANCE OF ENGINEERING STRUCTURES” (DYVIRT)}

PARAMETER INVESTIGATION OF RELAXED UNCERTAIN POWER SPECTRA FOR STOCHASTIC DYNAMIC SYSTEMS

Marco Behrendt, Marius Bittner, Liam Comerford, Matteo Broggi, Michael Beer

AN APPLICATION OF GENERATIVE ADVERSARIAL NETWORKS IN STRUCTURAL HEALTH MONITORING

George Tsialiamanis, Eleni Chatzi, N. Dervilis, David Wagg, Keith Worden

A NEAT APPROACH TO STRUCTURAL HEALTH MONITORING

George Tsialiamanis, David Wagg, N. Dervilis, Keith Worden

A PROBABILISTIC APPROACH TOWARDS UNCERTAINTY QUANTIFICATION IN JOINED STRUCTURES 
KALMAN-BASED COUPLED RESPONSE-INPUT ESTIMATION DURING ENVIRONMENTAL TESTS ON THE BOX ASSEMBLY WITH REMOVABLE COMPONENT STRUCTURE

Silvia Vettori, Emilio Di Lorenzo, Bart Peeters, Eleni Chatzi

COMPUTATIONALLY EFFICIENT HIERARCHICAL BAYESIAN MODELING FRAMEWORK FOR LEARNING EMBEDDED MODEL UNCERTAINTIES

Xinyu Jia, Omid Sedehi, Costas Papadimitriou, Lambros S. Katafygiotis

ON THE IMPLEMENTATION OF ADAPTIVE INVERSE CONTROL TO VIRTUAL TRANSFER SYSTEMS 3894

Thomas Simpson, Vasilis Dertimanis, Eleni Chatzi

ROBUST BAYESIAN OPTIMAL SENSOR PLACEMENT FOR MODEL PARAMETER ESTIMATION AND RESPONSE PREDICTIONS

Tulay Ercan, Petros Koumoutsakos, Costas Papadimitriou

UNCERTAINTY QUANTIFICATION FRAMEWORK FOR STRUCTURAL MODEL OF WIND TURBINE BLADES 3911

Paulo Gonzaga, Keith Worden, Nikolaos Dervillis, Nevena Stevanovic, Lars Oliver Bernhammer, Henrik Stensgaard Toft

\section{MS 32: COMPUTATIONAL METHODS FOR STOCHASTIC DYNAMICS}

SENSITIVITY ANALYSIS OF SAFETY PERFORMANCE OF THE BURIED PIPELINES UNDER SURCHARGE 3921

Zhiqiang Wang, Zhenyu Lei

INCREMENTS AND DIFFERENTIALS IN THE STOCHASTIC ANALYSIS OF FRACTIONAL DIFFERENTIAL EQUATIONS

Mario Di Paola, Antonina Pirrotta

\section{MS 33: NUMERICAL SIMULATIONS FOR EARTHQUAKE-RESILIENT SYSTEMS}

A DEVELOPED ANALYTICAL NON-LINEAR MODEL OF ELASTOMERIC BEARINGS VERIFIED WITH NUMERICAL FINDINGS

Konstantinos N. Kalfas, Davide Forcellini

EXPERIMENTAL, THEORETICAL, AND NUMERICAL SIMULATION APPROACHES TO ASSESS THE COMPRESSIVE BEHAVIOR OF ELASTOMERIC BEARINGS

Manuel Guzmán Sánchez, Davide Forcellini, Ricardo Moreno Sánchez, Diego Giraldo-Vásquez 
THE ROLE OF NON-LINEARITY IN THE SEISMIC ASSESSMENT OF A BASE ISOLATED BENCHMARK BUILDING WITH SOIL STRUCTURE INTERACTION EFFECTS

Andrea Canini

SENSITIVITY OF DEFORMATION DEMANDS IN BUILDINGS TO MODELING ASSUMPTIONS IN NONLINEAR SEISMIC ANALYSIS

Jørgen Rosmo Roven, Emrah Erduran, Amir M. Kaynia

EFFECT OF THE JOINT STRENGTH ON THE PERFORMANCE OF ORDINARY MOMENT-RESISTING FRAMES UNDER A PROGRESSIVE COLLAPSE SITUATION 3995

Mohammad Ali Mahdavipour, Dmitry Vysochinskiy

NUMERICAL SIMULATIONS OF UNBURIED HP/HT SUBSEA PIPELINES SUBJECTED TO SEISMIC SCENARIOS 4007

Daniele Mina, Davide Forcellini, Hassan Karampour

GRAVITY SYSTEM ENERGY DISSIPATION CONTRIBUTION IN SEISMIC PERFORMANCE OF SPECIAL STEEL MOMENT FRAMES 4023

Francisco Flores, Sebastian Pozo, Bryam Astudillo, Jose Vazquez

SIMULATING THE CYCLIC BEHAVIOUR OF A SINGLE-BAY WIDE-FLANGED STEEL BRACED FRAME 4039 Madhar Haddad, Nigel Shrive

NUMERICAL SIMULATIONS OF ELASTOMERIC BEARINGS BRACED WITH STEEL CABLES UNDER CYCLIC DISPLACEMENT 4049

Hossain Talebi, Mohammad Reza Adibramezani, Nooshin Ghorbani Amirabad

CYCLIC BEHAVIOUR AND FRACTURE OF A SINGLE-BAY WIDE-FLANGED STEEL BRACED FRAME 4059 Madhar Haddad, Nigel Shrive

\section{MS 34: VIBRATION ABSORPTION}

EFFECT OF DIFFERENT CONFIGURATIONS OF THE GEOFOAM FILLED BARRIER IN VIBRATION SCATTERING AND ITS OPTIMIZATION BY GENETIC ALGORITHM

Mehran Naghizadehrokni, Martin Ziegler

EXPERIMENTAL INVESTIGATION OF 2D RAINBOW PHONONIC CRYSTALS FOR BROADBAND VIBRATION ATTENUATION 4085

Han Meng, Dimitrios Chronopoulos, Nick Bailey, Zhuang Dong, Jian Yang

ACOUSTIC PERFORMANCE EVALUATION OF A PANEL UTILIZING NEGATIVE STIFFNESS MOUNTING FOR LOW FREQUENCY NOISE CONTROL 4093

Andreas Paradeisiotis, Moris Kalderon, loannis Antoniadis, Lina Fouriki

A MACHINE MOUNT BASED ON THE KDAMPER FOR VIBRATION ABSORPTION AT LOW FREQUENCIES 4111 Andreas Paradeisiotis, Konstantinos Tsioumanis, loannis Antoniadis, Kalliopi Fouriki 
DESIGN OF A BROADBAND ELASTIC METAMATERIAL VIA TOPOLOGICALLY OPTIMIZED INERTIAL AMPLIFICATION MECHANISMS

Osman Yuksel, Cetin Yilmaz

VIBRATION ABSORPTION PERFORMANCE OF METAMATERIAL LATTICES CONSISTING OF IMPACT DAMPERS

Kyriakos Chondrogiannis, Vasilis Dertimanis, Sami Masri, Eleni Chatzi

SEISMIC RESPONSE OF STRUCTURE EQUIPPED WITH A NON-INVASIVE EXTERNAL VISCOUS DAMPING SYSTEM 4150

Antonio Sabino, Antonio Mannella

ADVANCED NEGATIVE STIFFNESS VIBRATION ABSORBERS COUPLED WITH SOIL-STRUCTURE INTERACTION FOR SEISMIC PROTECTION OF BUILDINGS

Konstantinos Kapasakalis, Antonios Alvertos, Antonios Mantakas, loannis Antoniadis, Evangelos Sapountzakis

OPTIMAL DESIGN OF ADVANCED NEGATIVE STIFFNESS ABSORBERS 4177

Konstantinos A. Kapasakalis, loannis A. Antoniadis, Evangelos J. Sapountzakis

DYNAMIC ANALYSIS OF AN ACTIVE ISOLATION MOUNT USING FEEDFORWARD AND FEEDBACK CONTROL SCHEMES 4189

Grigorios Chatziathanasiou, Nikolaos Chrysochoidis, Dimitris Saravanos

MS 35: NEW TRENDS IN THE COMPUTATIONAL AND EXPERIMENTAL STRUCTURAL DYNAMICS FOR THE PRESERVATION OF HISTORICAL MASONRY STRUCTURES IN SEISMIC AREAS

AN INNOVATIVE VOXEL-BASED APPROACH FOR THE OUT-OF-PLANE HOMOGENIZED LIMIT ANALYSIS OF NON-PERIODIC MULTI-LEAF MASONRY WALLS

Gabriele Milani, Simone Tiberti

EXPERIMENTAL AND NUMERICAL STUDY OF HISTORIC MASONRY WITH BED JOINT REINFORCED REPOINTING

Anastasios Drougkas, Lucia Licciardello, Jan G. Rots, Rita Esposito

SEISMIC VULNERABILITY EVALUATION OF LONGHU PAGODA, SICHUAN, PRC

Peixuan Wang, Jacopo Scacco, Gabriele Milani, Shengcai Li

ADAPTIVE LIMIT ANALYSIS OF HISTORICAL MASONRY STRUCTURES MODELED AS NURBS SOLIDS 4243

Nicola Grillanda, Andrea Chiozzi, Gabriele Milani, Antonio Tralli

AN AUTOMATIC AND FAST PROCEDURE FOR THE NUMERICAL ANALYSIS OF CURVED MASONRY STRUCTURES 4255

Jacopo Scacco, Gabriele Milani, Paulo Lourenço 
THE MODELLING OF MULTIPLE LEAF MASONRY WALLS OF THE ARQUATA DEL TRONTO FORTRESS AS A NON-SMOOTH DYNAMICAL SYSTEM

Angela Ferrante, Ersilia Giordano, Francesco Clementi, Vasilis Sarhosis, Gabriele Milani, Stefano Lenci

DAMAGE ASSESSMENT OF CHURCHES IN THE CITY OF CAMERINO AFTER THE 2016 CENTRAL ITALY SEISMIC SEQUENCE

Ersilia Giordano, Angela Ferrante, Francesco Clementi, Stefano Lenci

AUTOMATIC ASSESSMENT OF PARTIAL FAILURE MECHANISMS IN RETROFITTED HISTORICAL MASONRY AGGREGATES THROUGH ADAPTIVE NURBS LIMIT ANALYSIS

Nicola Grillanda, Marco Valente, Gabriele Milani

MITIGATION OF AMPLIFIED RESPONSE OF RESTRAINED ROCKING WALLS THROUGH HORIZONTAL DAMPERS

Fabio Solarino, Linda Giresini, Daniel V. Oliveira

THE SPECTRAL ACCELERATION IN THE SEISMIC VULNERABILITY ASSESSMENT OF A HISTORIC MASONRY BUILDING. A COMPARISON BY USING SEVERAL APPROACHES ON A CASE STUDY 4304

Renato Sante Olivito, Saverio Porzio, Carmelo Scuro

FRAGILITY ASSESSMENT OF UNREINFORCED MASONRY WALLS UNDERGOING EARTHQUAKE-INDUCED LOCAL FAILURE MECHANISMS

Marco Nale, Andrea Chiozzi, Riccardo Lamborghini, Fabio Minghini, Marco Rigolin, Antonio Tralli

SEISMIC VULNERABILITY COMPARATIVE ASSESSMENT OF SOME SAMPLES OF CHURCHES AFFECTED BY LAST ITALIAN EARTHQUAKES

Generoso Vaiano, Michele D'Amato, Antonio Formisano

A MULTIDISCIPLINARY APPROACH FOR THE ASSESSMENT OF THE DYNAMIC AND SEISMIC BEHAVIOUR OF ARCHAEOLOGICAL STRUCTURES IN HIERAPOILIS OF PHRIGYA, TURKEY 4340

F. Lorenzoni, M. Salvalaggio, M.R. Valluzzi, J. Boaga, R. Deiana

\section{MS 36: DAMPING MODELLING AND EXPERIMENTS}

VALIDATION OF A STRUCTURAL MODEL OF A LARGE TIMBER TRUSS WITH SLOTTED-IN STEEL PLATES AND DOWELS

Pierre Landel, Andreas Linderholt

MS 37: CONSERVATION, RETROFIT AND STRENGTHENING OF EXISTING STRUCTURES: INNOVATIONS IN APPLIED METHODS AND MATERIALS

SHEAR STRENGTHENING OF MASONRY PANELS USING A GFRP-REINFORCED MORTAR COATING 4358

G. Castori, E. Speranzini, M. Corradi, S. Agnetti, G. Bisciotti 


\section{MS 38: GENERAL SESSION ON STRUCTURAL DYNAMICS, STABILITY AND VIBRATIONS}

ANALYSIS OF RC CONTAINMENTS OF NUCLEAR PLANTS UNDER AEROPLANE IMPACT LOADS

Mohamed Ihab S. Elmasry, Nabil H. Alashkar, Mostafa M. Hassan

DESIGN AND ANALYSIS OF AN X-STRUCTURED VIBRATION ISOLATION MOUNT (X-MOUNT) WITH WIDER QUASI-ZEROSTIFFNESS RANG

Jing Bian, Xingjian Jing

CALCULATION DISPERSIONS AND ERRORS OF SHIP HULL AND SUPERSTRUCTURE VIBRATIONS 4441 Lech Murawski, Do Van Doan

EVALUATION OF A PUSHOVER PROCEDURE FOR ASYMMETRIC R/C BUILDINGS WITH VARIOUS TORSIONAL PROPERTIES

Grigorios Manoukas, Asimina Athanatopoulou

OPTIMUM STRUCTURAL DESIGN OF A CUBESAT SUBJECTED TO LAUNCHER MECHANICAL ENVIRONMENT 4467

Adham Adel, Amir Tawfik, Eslam Saleh, Hesham Ibrahim

WIND EFFECTS ON LOW-RISE BUILDINGS WITH NEIGHBOURING STRUCTURE AS OBSTACLES

Josue U. Rodriguez-Alcantara, Adrian Pozos-Estrada, Roberto Gomez-Martinez

FLEXURAL PERFORMANCE OF DOUBLE HOOKED END STEEL FIBRE REINFORCED CONCRETE BEAMS UNDER CYCLIC LOADING

Demewoz Menna, Aikaterini Genikomsou, Mark Green

DISCUSSION ON THE CAPACITY DESIGN OF COLUMNS IN LOW-RISE BARE AND INFILLED RC MOMENT FRAMES

Alexios Papasotiriou, Asimina Athanatopoulou

ELASTIC AXIS OF BUILDINGS UNDER EARTHQUAKE EXCITATION 4512

Vasiliki Terzi, Asimina Athanatopoulou

EVALUATION OF VIBRATION CHARACTERISTICS OF RC AND PPC BEAM MEMBERS UNDER CYCLIC TRAIN LOADING

Munemasa Tokunaga

EXPERIMENTAL STUDY ON THE FRACTURE BEHAVIOR OF AN RC PILE GROUP FOUNDATION USING A CENTRIFUGE MODEL

Yuichi Miyachi, Kazuhiro Hayashi, Shuhei Takahashi, Taiki Saito

SSI EFFECTS ON R/C ONE-STOREY BUILDINGS UNDER SEISMIC LOADINGS 4545

Paraskevi K. Askouni, Dimitris L. Karabalis, Dimitri E. Beskos 
THE RESPONSE OF DIFFERENT BUILDINGS TO FREE-FIELD EXCITATION - A STUDY USING DETAILED FINITE ELEMENT MODELS 4560

Lutz Auersch, Susanne Ziemens

INVESTIGATION OF AN ACTIVELY CONTROLLED ROBOT ARM FOR VIBRATION SUPPRESSION IN MILLING .4577

Muhammet Ozsoy, Neil D. Sims, Erdem Ozturk

AN EVALUATION OF THE CURRENT APPROACHES AND RECOMMENDATIONS FOR MORE RATIONAL APPROACHES FOR ASSESSING THE SEISMIC TORSIONAL STABILITY OF BUILDINGS 4590 Bryam Astudillo, Francisco Flores, Sebastian Pozo, Finley Charney

VIBRATION CONTROL BY STRUCTURAL COUPLING IN ADJACENT STRUCTURES USING STOCHASTIC ANALYSIS ....4601 Augusto Pippi, José Luis de Brito, Suzana Avila, Graciela Doz

STUDY OF A HYBRID INVERTED PENDULUM TUNED MASS DAMPER BEHAVIOR USING A PID CONTROLLER 4615 Jonas Pereira Falcão, Ledymar Foncault Moreno, José Luis Vital de Brito, Marcus Vinicius Girão de Morais, Suzana Moreira Avila

A COMPARISON OF GAIN DESIGN CRITERIA FOR CLOSED-LOOP MODEL UPDATING 4630 Lars Lynge Hansen, Thomas Akselsen, Ünal Korkmaz, Martin Dalgaard Ulriksen

ADEQUACY OF ACCIDENTAL ECCENTRICITY IN ACCOUNTING FOR THE EFFECTS OF THE TORSIONAL COMPONENT OF EARTHQUAKES ON THE SEISMIC DAMAGE 4639

Konstantinos Morfidis, Konstantinos Kostinakis, Nikolaos Pneymatikos

SUB-STRUCTURING APPROACH OF THE PREDICTION OF BUILDING VIBRATIONS INDUCED BY RAILWAY TRAFFIC 4651

Chao He, Shunhua Zhou, Peijun Guo, Honggui Di

A TUNED MASS DAMPER INERTER CONTROL DEVICE FOR BASE ISOLATED STRUCTURES 4663

Salah Djerouni, Mouncef Eddine Charrouf, Abdelhafid Ounis, Mahdi Abdeddaim, Nassim Djedoui

FUNDAMENTAL PERIOD RELATIONSHIP OF RC-BUILDINGS IN ALICANTE PROVINCE (SPAIN). A FIRST STEP TO SOIL-STRUCTURE RESONANCE MAPS 4678

Noelia Agea-Medina, Alireza Kharazian, Sergio Molina, Juan José Galiana-Merino, Juan Luís Soler-Llorens

MEASURING THE DYNAMIC DISPLACEMENTS OF BRIDGES USING GEOPHONE DATA: APPLICATION AND VALIDATION ON A LIVELY FOOTBRIDGE 4687

Paolo Borlenghi, George Piniotis, Harris Perakis, Vassilis Gikas, Carmelo Gentile

SEISMIC RESPONSE OF ADJACENT BUILDING STRUCTURE CONNECTED WITH SUPERELASTIC DAMPER: COMPARISON WITH YIELD DAMPER 4696 Sourav Gur, Pranay Singh, Koushik Roy

SURFACE WAVE PROPAGATION FROM DROP-PROJECTILE TESTS: PHYSICAL AND NUMERICAL MODELLING 4710 Vipul Kumar, S.P.G Madabhushi 
Diego Alexander Tibaduiza, Jersson León, Luis Bonilla, Bernardo Rueda, Oscar Zurita, Juan Carlos Forero, Jaime Vitola, Dario Segura, Edwin Forero, Maribel Anaya

ON THE ESTIMATION OF VON MISES EQUIVALENT STRESS IN RANDOM VIBRATION ANALYSIS 4730

Federico Perotti, Francesco Foti, Luca Martinelli

INTERRELATION BETWEEN NEW HILBERT-HUANG TRANSFORM-BASED SEISMIC INTENSITY PARAMETERS AND STRUCTURAL DAMAGE

Magdalini Tyrtaiou, Anaxagoras Elenas

TYPHOON FRAGILITY ANALYSIS AND CLIMATE CHANGE IMPACT ASSESSMENT OF FILIPINO CULTURAL HERITAGE ASSET ROOFS

Giacomo Sevieri, Carmine Galasso

MODAL PROPERTIES OF A FLOOR WITH SINGLE-LEAF PLYWOOD ON TIMBER JOISTS: EXPERIMENTAL AND NUMERICAL MODELLING

Lars Vabbersgaard Andersen, Nina Jørgensen, Gitte Skovlund Iversen, Jannick Balleby Hansen

COMPARATIVE EVALUATION OF THE METHODS PROPOSED BY THE GREEK CODE FOR STRUCTURAL INTERVATION (KAN.EPE.) FOR THE ESTIMATION OF CURVATURE DUCTILITY 4799

Konstantinos Morfidis, Christos Karakostas, Sotiria Stefanidou

SEISMIC PERFORMANCE OF EXISTING BUILDINGS CONCRETE SHEAR WALL 4816

Sk Amjad Hossain, Ashutosh Bagchi

EFFECTS OF ALTERNATING AXIAL FORCES ON THE RECYCLING RESPONSE OF REINFORCED CONCRETE FRAMES STRENGTHENED BY TENSION-TIES 4826

Angelos Liolios, George Hatzigeorgiou, Panagiotis Panetsos, Dimitrios Konstantinidis

CORRECTION OF LASER DOPPLER VIBROMETER MEASUREMENTS AFFECTED BY SENSOR HEAD VIBRATION USING TIME DOMAIN TECHNIQUES 4842

Abdel Darwish, Ben Halkon, Sebastian Oberst, Robert Fitch, Steve Rothberg

THE DISSIPATIVE CHARACTERISTICS OF OBLATE PARTICLES IN GRANULAR DAMPERS 4851

Furkan Terzioglu, Jem A. Rongong, Charles E. Lord

PREDICTION OF BEAM DYNAMICS IN CABLE-BEAM SYSTEMS THROUGH EXPERIMENTAL-NUMERICAL DECOUPLING

Mohammad Hadi Jalali, Geoff Rideout

CONTRIBUTION OF SEISMIC NOISE RECORDINGS TO THE NON-STRUCTURAL VULNERABILITY ASSESSMENT 4878

Konstantinos G. Megalooikonomou

STRUCTURAL HEALTH MONITORING OF A PASSIVE VIBRATION CONTROLLED STRUCTURE 4887

Tsutomu Ochiai, Tetsushi Inubushi, He Ma, Manuel Navarro, Takahisa Enomoto 
DYNAMIC RESPONSE OF TALL TIMBER BUILDINGS UNDER SERVICE LOAD - THE DYNATTB RESEARCH PROGRAM 4900

Rune Abrahamsen, Magne A Bjertnæs, Jacques Bouillot, Bostjan Brank, Lionel Cabaton, Roberto Crocetti, Olivier Flamand, Fabien Garains, Igor Gavric, Olivier Germain, Ludwig Hahusseau, Stephane Hameury, Marie Johansson, Thomas Johansson, Wai Kei Ao, Blaž Kurent, Pierre Landel, Andreas Linderholt, Kjell Malo, Manuel Manthey, Petter Nåvik, Alex Pavic, Fernando Perez, Anders Rönnquist, Haris Stamatopoulos, Iztok Sustersic, Salue Tulebekova

SEISMIC RISK ASSESSMENT OF A MEDIEVAL TOWER: THE CASE STUDY OF CRACO 4911 Michela Lerna, Maria F. Sabbà, Mariella Diaferio, Leonarda Carnimeo, Salvador Ivorra, Dora Foti

DYNAMIC ANALYSIS OF A POMPEIAN DOMUS 4922

Michela Monaco, Antonino lannuzzo, A.Tafuro, Antonio Gesualdo

SHEAR PLASTIC DYNAMIC BEHAVIOUR OF WIND TURBINE TOWERS 4930

Antonio Gesualdo, Francesco Penta, Antonino lannuzzo, Michela Monaco

ON THE AXIAL FORCE IDENTIFICATION IN EULER-BERNOULLI BEAMS WITH UNKNOWN BOUNDARY CONDITIONS 4944

Margaux Geuzaine, Francesco Foti, Vincent Denoël

SEISMIC VULNERABILITY ASSESSMENT OF A ROMANIAN HISTORICAL BUILDING UNDER NEAR-FIELD EARTHQUAKE

Nicola Chieffo, Antonio Formisano, Marius Mosoarca, Paulo B. Lourenço

VIBRATION MONITORING OF CONSTRUCTION WORK AND INDUSTRIAL ACTIVITIES USING NEW SOLUTIONS OF INSTRUMENTATION 4972

Carlos Moutinho, Alvaro Cunha 


\title{
AN INTEGRATED MONITORING STRATEGY FOR CURRENT CONDITION ASSESSMENT OF HISTORIC BRIDGES
}

\author{
Gabriele RAVIZZA ${ }^{1}$, Rosalba FERRARI ${ }^{1}$, Egidio RIZZI ${ }^{1^{*}}$, \\ Vasilis DERTIMANIS ${ }^{2}$ and Eleni N. CHATZI ${ }^{2}$ \\ ${ }^{1}$ University of Bergamo, Department of Engineering and Applied Sciences, \\ viale G. Marconi 5, I-24044 Dalmine (BG), Italy \\ ${ }^{*}$ Corresponding Author, e-mail: egidio.rizzi@unibg.it \\ ${ }^{2}$ ETH Zürich, Institute of Structural Engineering, \\ Department of Civil, Environmental and Geomatic Engineering, \\ Stefano-Franscini-Platz 5, CH-8093 Zürich, Switzerland
}

Keywords: Structural Health Monitoring (SHM); Heterogeneous Data Fusion (HDF); Denoising techniques; historic reinforced concrete bridge; acceleration data; displacement data; modal identification.

\begin{abstract}
Nowadays, the need for effective Structural Health Monitoring (SHM) strategies, aiming at preserving the integrity and safety of strategic and historic infrastructures, is increasingly urgent. Within SHM, several vibration-based methodologies have been developed, including those exploiting Heterogeneous Data Fusion (HDF) procedures, as well as Denoising techniques for the treatment of response signals detected through appropriate sensor technologies. In this paper, these two approaches are reconsidered and rejoined, toward developing an innovative signal processing methodology for current condition assessment, specifically referring to historic bridges. In particular, a HDF approach, i.e. the process of combining information from multiple sources, in an effort to enhance the reliability of the monitoring process, and a denoising approach, devoted to the cleaning of spurious noise from the acquired signals, are combined all together, in an integrated strategy. The effectiveness of the proposed platform is tested on data from a real structure (historic bridges). Both dynamic acceleration and displacement response signals, directly detected under operational conditions, can be processed within the proposed methodology, and subsequently employed toward modal dynamic identification purposes and possible model updating of the structure at hand.
\end{abstract}




\section{INTRODUCTION}

This study is motivated by the awareness quest on the critical health conditions that may characterize existing and historical infrastructures, especially those nearing the end of their life cycle. Despite their age, these structures often continue to play a critical role in everyday life, constituting essential connections within the transportation network of several territories and communities. Consequently, a prompt and effective adoption of appropriate and modern strategies and action models toward their conservation and protection shall be set in place. In this scenario, the development of monitoring-based strategies toward structural condition assessment of such important infrastructures, shall constitute a fundamental tool toward the competent analysis.

Accordingly, within the civil engineering context, the Structural Health Monitoring (SHM) research field is becoming increasingly important, since the goal of achieving structural safety is only possible through the possibility to extract more abundant and precise information about the health conditions of a structure to be monitored, for instance by analyzing its current structural dynamic response. As a consequence, within SHM applications, after the signal acquisition stage, to be acquired directly on the structure by predisposing appropriate sensor networks, the subsequent phase of signal processing displays a determinant role, toward the success of the whole monitoring procedure.

In this paper, two complementary and possibly interacting approaches for the post-processing of structural response signals are considered, i.e. a denoising approach, as well as a Heterogeneous Data Fusion (HDF) procedure, aiming at achieving a better screening of real structural response signals, which may be corrupted by some amount of noise, especially in case of a low-cost instrumentation.

In particular, denoising techniques aim at clarifying the signal content, by directly acting on the contaminating noise, reducing its amount, while preserving the useful information embedded in the signal itself. Several denosing-based techniques may be employed for this purpose, including those exploiting Singular Value Decomposition (SVD) or Discrete Wavelet Transform (DWT), as recently investigated in Ravizza et al. [18,19], where the effectiveness of these approaches has been inspected for both stationary (ambient vibration) and non stationary (seismic excitation) synthetic response signals, and for instances of real vibration signals.

Instead, Heterogeneous Data Fusion (HDF)-based approaches are procedures through which heterogeneous measurements may be combined all together, with the analogous purpose to enhance their quality, by alleviating the amount of noise on the signals and, consequently, reducing the induced uncertainties affecting the monitoring results. Several virtuous examples of HDF applications within the civil engineering field may be found in the literature, as for instance in Chatzi and Fuggini [2,3], Ferrari et al. [4-6] and in Ravizza et al. [17], where a Kalman Filter (KF) has been involved in a HDF scheme between artificially generated acceleration and displacement response signals, aiming at obtaining enhanced displacement response measurements, for a 3-DOFs numerical dynamic system.

In the present investigation, a denoising-based approach, and a HDF procedure are considered all together and possibly coupled within an integrated monitoring methodology for the purification of real response signals, specifically displacement signals, which usually appear to be affected by higher levels of noise, if compared to accelerations. The obtained post-processed enhanced displacement measurements may then be employed toward modal dynamic identification purposes (see e.g. Pioldi et al. [10-12] and Pioldi and Rizzi [13-16]), and this might result of a crucial interest for real applications related to the SHM context. 
Although the proposed methodology aims at a general formulation, as to be suitable for the monitoring of different structural systems, here, a specific real test structure is assumed as a case study for the analysis, in order to highlight the feasibility of the proposed monitoring strategy and show its effectiveness. For this purpose, the historic reinforced concrete (RC) bridge at Brivio (1917), i.e. a strategic infrastructure for some local connections within the northern Italy automotive road notwork, has been considered (Santarella and Miozzi [20], Ferrari et al. [7]).

The multiple goals that this study aims at achieving are:

- to pursue an effective denoising of real acceleration response data, detected on the monitored structure, through appropriate (wireless) acceleration sensors. In fact, although accelerations usually display a good resolution, when the sensor instrumentation employed during the signal acquisition stage is somehow poor, this may become necessary;

- to successfully perform a denoising-based approach on the original (raw) displacement signals, aiming at clarifying their content in the time domain, then resulting in a better representation and reading of the time domain signal features;

- to perform a successful HDF, by involving a KF within the fusion procedure between denoised acceleration and denoised displacement response signals, in order to obtain a further enhancement of the displacement data in the time domain;

- to employ the enhanced displacements, downstream from the HDF processing, toward possible modal dynamic identification purposes within the frequency domain, aiming at estimating the modal characteristics of the considered infrastructure.

To prove that the proposed monitoring methodology is competitive, leading to visible benefits to the structural identification process, the modal natural frequencies identified from postprocessed displacements are then compared with the frequencies identified from raw data. The effectiveness of the method is proven, as well as its possible generalization to different typologies of structures.

The paper is organized as follows. In Section 2, a brief description of the structure of interest is outlined, with the reasons behind the choice of taking the Brivio bridge as a benchmark structure for the present analysis. In Section 3, the proposed monitoring strategy is formulated and presented. Then, the obtained results are reported and discussed in Section 4. Finally, last remarks and summary comments are provided within the conclusions reported in Section 5.

\section{PRESENTATION OF THE MONITORED STRUCTURE}

The peculiar class of structural systems to which this study is addressed to, aims at covering civil engineering structures characterized by a significant and strategic importance, possibly combined with a historical-architectural value. In particular, the monitored structure considered as a case study within the current analysis, is the RC Brivio bridge (1917) (Santarella and Miozzi [20], Ferrari et al. [6]), represented in following Fig. 1.

The bridge, located in northern Italy (Lombardia region), constitutes an important automotive connection between the provinces of Lecco and Bergamo, linking the banks of the Adda river (Brivio (LC) and Cisano Bergamasco (BG)), at an approximate height of $8 \mathrm{~m}$ from water.

About its description, the Brivio bridge consists of three spans, each characterized by a couple of parabolic arches, symmetrically located to the mid-longitudinal plane. The two spans 


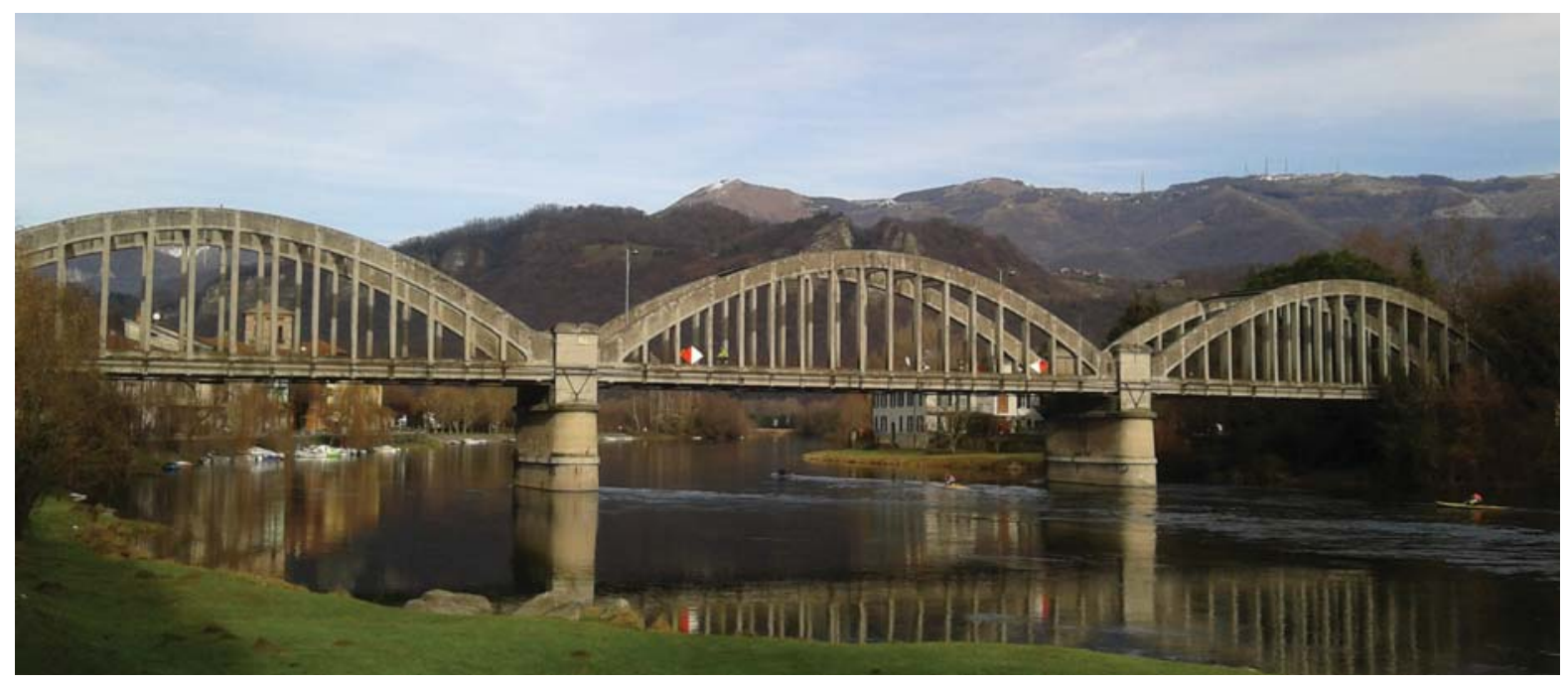

Figure 1: RC three-span arched Brivio bridge (1917) over the Adda river.

aside the river banks are $43.4 \mathrm{~m}$ long; the central span is $44 \mathrm{~m}$ long, for a total length of $130.8 \mathrm{~m}$. The deck is $9.2 \mathrm{~m}$ wide and hosts two roadway lanes and two cantilever sidewalks, of a $0.8 \mathrm{~m}$ width each. The deck structural frame of each span is constituted by a grid supporting a RC slab of a thickness of $0.15 \mathrm{~m}$. The peculiar parabolic arches of the bridge display a span of $42.80 \mathrm{~m}$ and a rise of $8.00 \mathrm{~m}$. The symmetric arches show a cross section that is $0.60 \mathrm{~m}$ wide, with a height varying from $1.25 \mathrm{~m}$ (at the middle) to $1.37 \mathrm{~m}$ (at the ends). Sixteen vertical RC hangers, characterized by a rectangular cross section of sides of $0.32 \mathrm{~m}$ and $0.60 \mathrm{~m}$, connect the deck to each arch. The bridge is supported on the river bed through two tapered concrete piers, each one presenting maximum dimensions at the basis equal to $12.8 \mathrm{~m}$ (transverse direction) and $3.8 \mathrm{~m}$ (longitudinal direction). The piers rest on foundation RC piles driven into the riverbed for a depth of $13 \mathrm{~m}$ to $16 \mathrm{~m}$ (Froio and Zanchi [9]).

The choice of Brivio bridge being taken as a benchmark structure for this study is motivated by the fact that, despite its age of more than one hundred years, the bridge is still subjected to continuous traffic loading, likely much heavier than that for which it was originally designed way back in 1917. Present use includes daily transit of heavy-duty and various vehicles in both rush hours and all day long. Indeed, similarly to other bridges located in the nearby territories (see e.g. the Paderno d'Adda bridge, Ferrari et al. [8], placed south downstream for just a few kilometers), the Brivio bridge still plays a crucial role in the local transportation network and, for this reason, it may largely benefit from a condition monitoring under operational conditions.

It is worth noting that all signals processed in the present analysis have been acquired during a three-day measurement campaign, performed directly on the Brivio bridge, in June 2014. Further details about such a measurement campaign, as for instance information about the employed measurement instrumentation, as well as on the sensor location, may be found in Ferrari et al. [4-7].

\section{MONITORING METHODOLOGY DESCRIPTION}

In this section, a comprehensive monitoring strategy for the health condition assessment of historic bridges is presented, by specifically assuming for illustration the case study of the 
RC Brivio bridge under operational loading conditions. Both acceleration and displacement response signals, directly detected on the structure as an integrated sensor network are involved within the proposed scheme. In fact, acceleration-based and displacement-based recordings are commonly exploited towards vibration-based monitoring purposes, and the choice of which approach should be preferred, usually depends on the specific monitoring goals to be pursued, as well as on the physical configuration of the analyzed structure.

In particular, acceleration-based monitoring allows to detect changes in the structural health conditions, which may be revealed by identifying variations in the structural modal properties, such as natural frequencies, mode shapes or modal damping ratios, since these quantities may then be employed within damage detection strategies for the current condition assessment of the monitored structure. Displacement-based monitoring, on the other hand, is often exploited both for evaluating the presence of excessive loads under standard service conditions, and for quantifying regular operational loads (e.g. traffic), to serve as reference in bridge design practice.

In this sense, acceleration- and displacement-based monitoring approaches may be considered as complementary, in providing useful tools toward an effective global assessment of historic and strategic infrastructural systems. However, especially due to the increasing demand for the adoption of low-cost monitoring instrumentation during the signal acquisition stage, these measurements may typically be accompanied by a significant amount of noise, which contaminates the structural response itself, by increasing the induced uncertainties and rendering more difficult their employment for SHM purposes. Such a deleterious noise effect is generally more evident on displacement data rather than on acceleration data, due to the intrinsic limits characterizing the present displacement sensor technology.

To address this issue, in the proposed monitoring methodology, a denoising-based approach is possibly integrated with a HDF-based procedure, aiming at exploiting the (more reliable) acceleration measurements for clarifying the dynamic displacement response signal of the bridge, acquired by means of a non-contact QDaedalus system (Bürki et al. [1]). The so obtained purified displacement data may then be employed toward modal identification purposes, e.g. for extracting the natural frequencies and the mode shapes of the monitored structure, and assessing its current structural conditions.

The present methodology combines a time domain analysis and a frequency domain analysis, as illustrated in the flowchart of Fig. 2, representing a global conceptual view of the considered monitoring scheme.

The time domain analysis aims at a better appreciation of the raw displacement recordings, to be later exploited for modal identification purposes. In doing so, the additional availability of acceleration response data, collected by means of wireless MEMS accelerometers, can be taken at a disposal.

Differently from data acquired through wired piezoelectric accelerometers, which may be considered as a rather reliable recording devices, even such raw acceleration data may first need to be purified, by applying appropriate denosing techniques, for reducing the noise level affecting the signal, while preserving the useful information within the recorded signal. To this purpose, a Discrete Wavelet Transform (DWT)-based denoising technique is implemented within the monitoring platform, resulting in the clarification of the detected acceleration response signal. Details about the calibration of the DWT-based denoising settings, adopted within this study, are provided in the next section. It is worth mentioning that also a Singular Value Decomposition (SVD)-based approach might be employed for the denoising of dynamic response signals; however, dealing with non stationary signals, such as those involved in this analysis, 


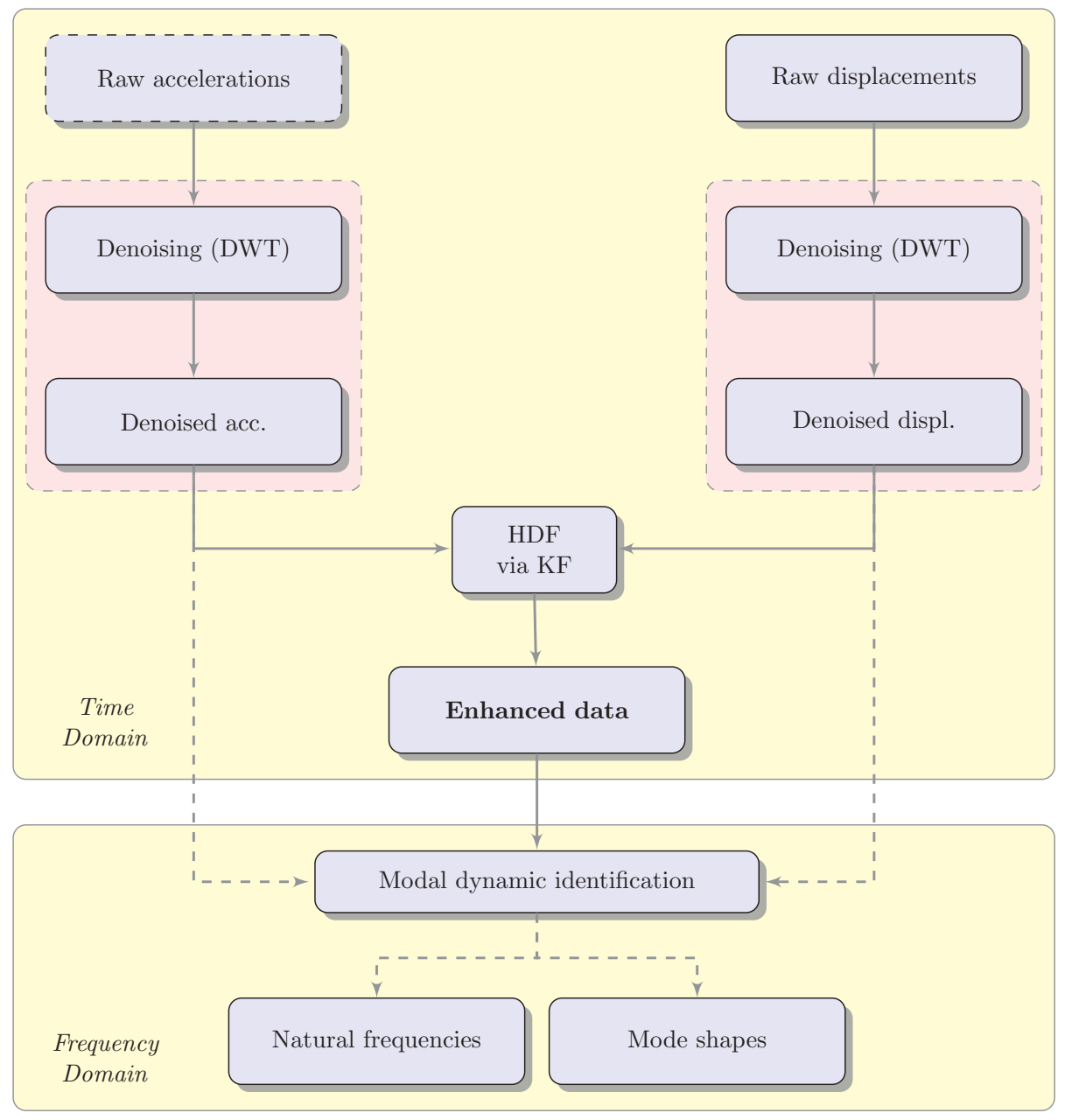

Figure 2: Flowchart of the proposed monitoring methodology, integrating a denoising-based and a $H D F$-based approach for the enhancement of response data collected on the structure, and a subsequent structural dynamic identification.

the DWT-based denoising approach should be preferred, as deeply shown and discussed in Ravizza et al. [18, 19].

In parallel to the (optional) acceleration denoising, a more frequently needed denoising of QDaedalus displacements is also foreseen. The same DWT-based technique is adopted, for the aforementioned reasons, and a preliminary cleaning effect on the signal is made achievable.

The core of the current implementation is now represented by the involvement of a Kalman filter (Chatzi and Fuggini [2]) within the HDF process, resulting in the merge of denoised QDaedalus displacements with acquired denoised accelerations, and an enhanced displacement response signal may be obtained.

A subsequent analysis within the frequency domain is also performed, in which the ambitious goal of successfully performing the modal dynamic identification on displacement data is inspected. In particular, the enhanced displacement response signal is employed for pursuing this purpose and, through an automatic peak-picking procedure performed on the Welch periodogram, the modal natural frequencies of the Brivio bridge may be identified. 
It is worth noting that, as it can be appreciated from the flowchart in Fig. 2, the monitoring platform also contemplates the possibility to perform the modal dynamic identification of the structure by solely using either the denoised accelerations or the denoised displacements (dashed arrows in Fig. 2), but the results may be less reliable, especially considering just the displacements. However, they can be exploited for comparative purposes, aiming at highlighting the benefits deriving from a HDF-based methodology in assessing the current health conditions of the specific analyzed bridge, although such a monitoring platform also aims at assuming a more general connotation, being useful for the structural monitoring of any characteristic infrastructure.

\section{RESULTS}

In this section, some first outcomes obtained by applying the proposed monitoring methodology to the real case of the RC Brivio bridge, are shown. Time domain analysis results are firstly presented, followed by outcomes derived from a subsequent analysis within the frequency domain. Signals are taken from a measurement campaign as acquired and reported in Ferrari et al. [6].

\subsection{Time domain analysis}

The present analysis (upper box in Fig. 2) aims at purifying a raw displacement signal, making its features to emerge more clearly in the time domain, through an effective HDF with recorded accelerations, supposed to be more reliable. However, in some cases, a preliminary denoising of such acceleration data may also become necessary, e.g. when the sensor instrumentation employed in the signal acquisition phase is not so performing. Therefore, a DWT-based denoising technique is implemented on the detected (original) accelerations (from wireless sensors), and the obtained denoised signal is reported in Fig. 3, as compared with the original one.

Given the non-stationary nature of the response data, a 60 seconds length acceleration response signal from a wireless sensor is denoised, by applying a DWT-based denoising technique, which shall best fit with this signal typology, as shown in Ravizza et al. $[18,19]$. In the same study, the optimal calibration of the parameters involved within this technique to deal with non-stationary signals is also inspected, resulting in the adoption of a Smylet 2 mother wavelet, combined with a Heursure hard thresholding rule, at decomposition level 2. Thus, the same setting is here assumed.

The effect of the denoising application is visible especially in the time window between $25 \mathrm{~s}$ and $40 \mathrm{~s}$, as it may be appreciated in Fig. 3, leading to a signal reduction of $6.58 \%$, in terms of Root Mean Square (RMS). The acceleration peak value is also considered, as it represents one most peculiar time domain signal feature, and a reduction of $9.11 \%$ is recorded. Such values are reported in following Table 1, for both the original and the denoised acceleration response signals.

An analogous DWT-based denoising approach is now implemented, for the preliminary clarification of the 60 seconds length QDaedalus displacement response signal, acquired on the Brivio bridge. Despite the very small amplitude of such recordings, which might affect the success of the denoising technique, the denoised estimates appear to be considerably clearer, if compared to the original (raw) data, as represented in Fig. 4. 


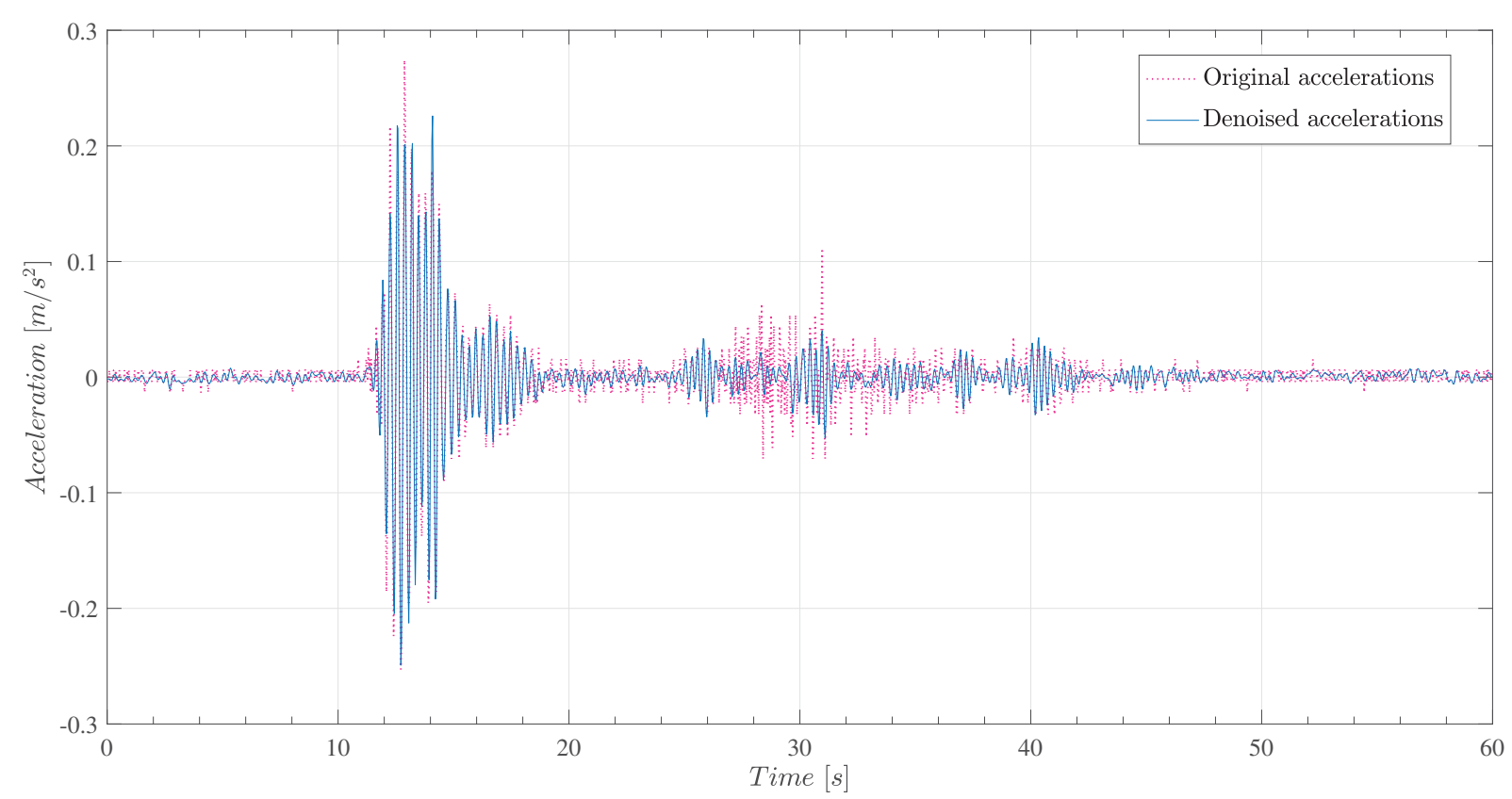

Figure 3: Brivio bridge (wireless) acceleration response signal, pre and post DWT-based denoising.

\begin{tabular}{lrrrr}
\hline Acceleration signal & RMS $\left[\mathrm{m} / \mathrm{s}^{2}\right]$ & $\Delta[\%]$ & Peak $\left[\mathrm{m} / \mathrm{s}^{2}\right]$ & $\Delta[\%]$ \\
\hline Original (raw) signal & 0.0319 & & 0.2742 & \\
DWT denoised signal & 0.0298 & -6.58 & 0.2492 & -9.11 \\
\hline
\end{tabular}

Table 1: Characteristic values of the analyzed acceleration response signals in the time domain and their variation with respect to the original (noise-affected) signal: RMS and peak acceleration values.

After this preliminary phase, devoted to the pre-treatment of the acquired data, the obtained denoised acceleration and displacement response signals are then processed within a HDFbased implementation, aiming at further enhancing the measured displacements, by enriching them through the information embedded within the denoised accelerations. To this end, a Kalman Filter algorithm is exploited, allowing for the effective merge of the two heterogeneous source signals (Chatzi and Fuggini [2], Ferrari et al. [6], Ravizza et al. [17]). The result is represented by a new enhanced displacement signal, as shown in Fig. 5, which more reliably reflects the response of the monitored bridge.

To complete the time domain analysis, RMS and peak deflection values of the displacement signals are also computed, and summarized in Table 2. A reduction of both values, although lighter than that recorded in the previous acceleration case, is still observable, configuring itself as a peculiar feature of such techniques, as shown for synthetic signals in Ravizza et al. [19]. 


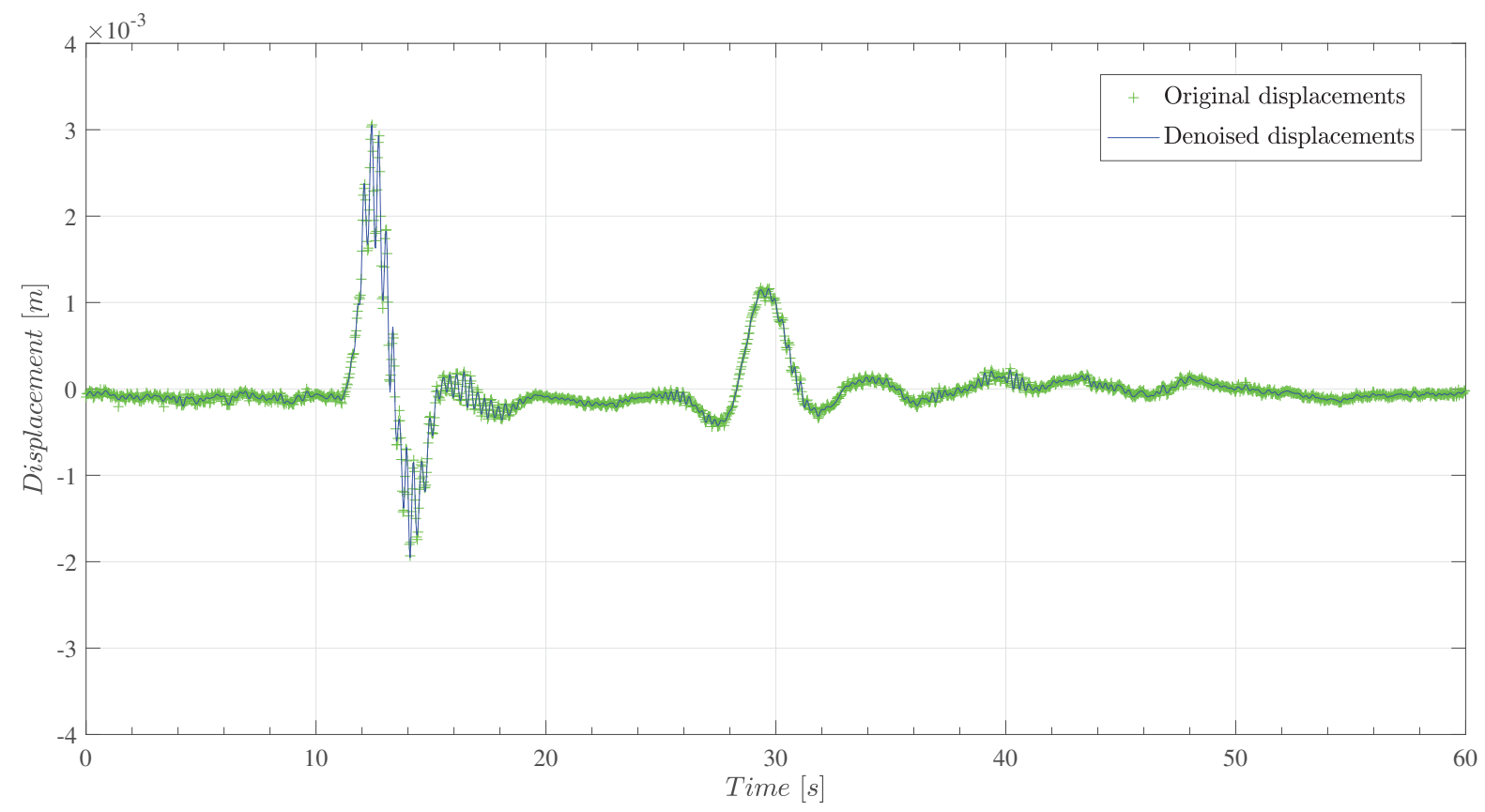

Figure 4: Brivio bridge (total station) displacement response signal, pre and post DWT-based denoising.

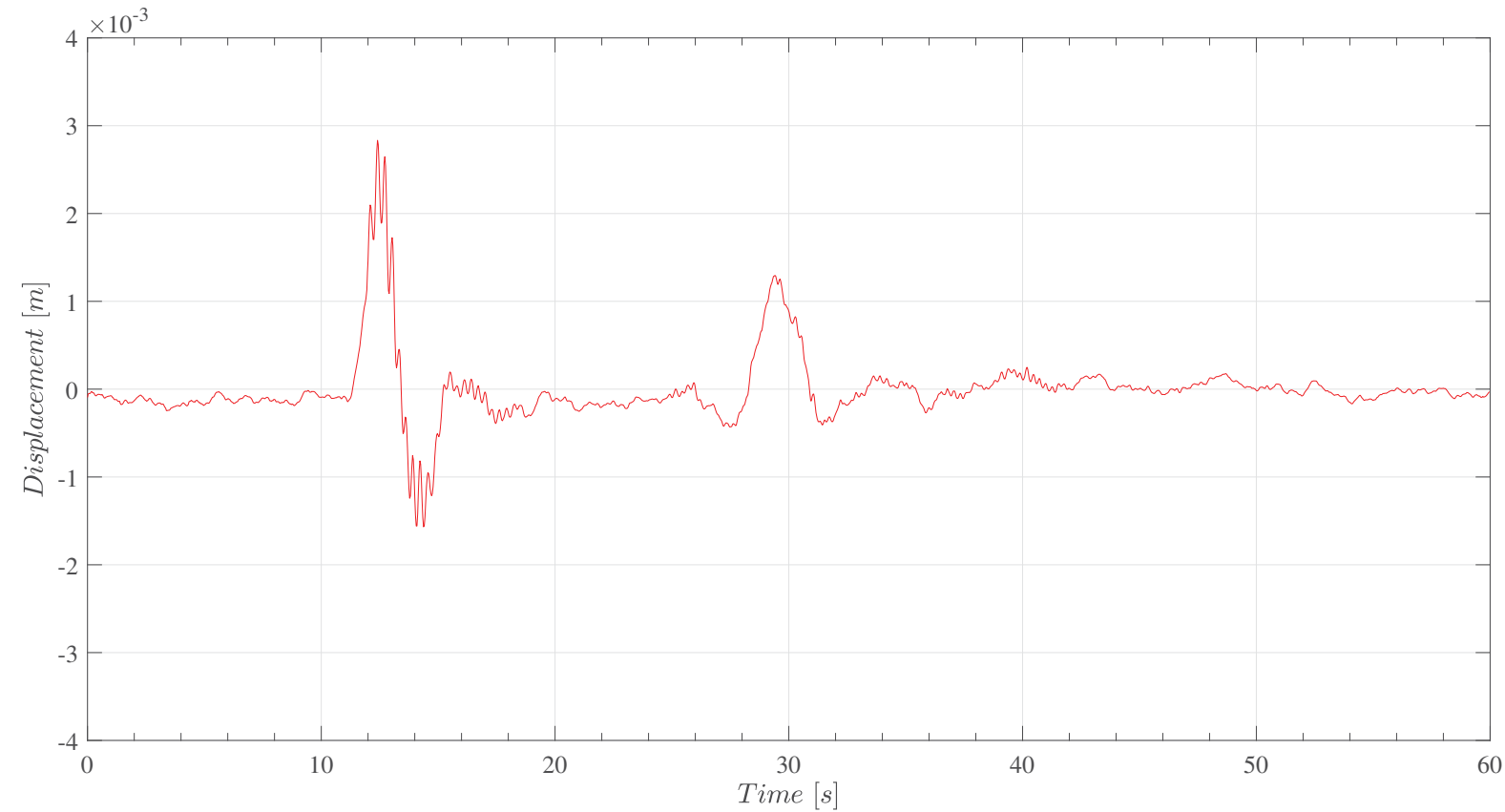

Figure 5: Enhanced Brivio bridge displacement response signal, obtained by HDF via KF with the denoised acceleration response signal. 


\begin{tabular}{lrrrr}
\hline Displacement signal & RMS $[\mathrm{mm}]$ & $\Delta[\%]$ & Peak $[\mathrm{mm}]$ & $\Delta[\%]$ \\
\hline Original (raw) signal & 0.4039 & & 3.056 & \\
DWT denoised signal & 0.4001 & -0.94 & 3.015 & -1.34 \\
HDF enhanced signal & 0.3972 & -1.66 & 2.833 & -7.30 \\
\hline
\end{tabular}

Table 2: Characteristic values of the analyzed displacement response signals in the time domain and their variation with respect to the original (noise-affected) signal: RMS and peak deflection values.

\subsection{Frequency domain analysis}

The enhanced displacement data, downstream obtained from the HDF procedure with the denoised accelerations, are now employed for performing a modal dynamic identification analysis in the frequency domain. In particular, by applying a Welch method on such displacements, the Power Spectral Density (PSD) function of the signal may be obtained. In following Fig. 6, the response spectrum derived from the HDF displacement signal and from the original (raw) displacement signal are represented and compared.

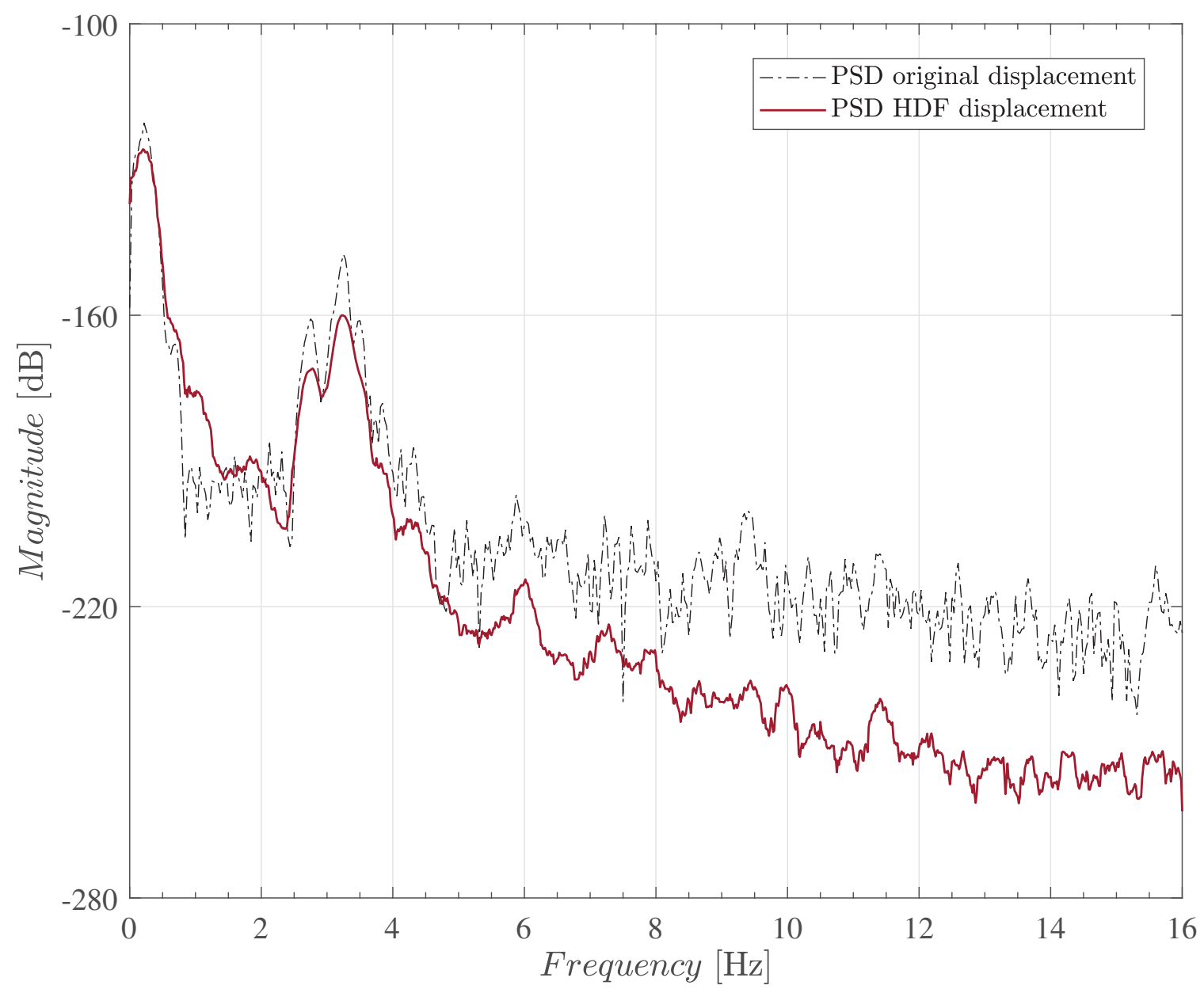

Figure 6: Brivio Bridge displacement (PSD) response spectrum: original (raw) displacement signal vs. HDF (enhanced) displacement signal. 
The effect of the previously applied time domain filtering techniques (i.e. DWT-based denoising and KF application) is evident, resulting in smoother curves, as well as in the reduction of the signal magnitude, especially within the medium-high frequency region (approximately greater than $6 \mathrm{~Hz}$ ), where the embedded noise mainly affects the data.

The benefits that the proposed methodology has brought to the identification process emerge by the comparison between the frequency content of the two signals. In fact, whether the original signal allows for the detection of just one frequency peak, corresponding to the first natural frequency of the bridge, the post-processed displacement signal reveals a greater number of frequency response peaks, which were previously indistinguishable, due to the deleterious effect of spurious noise. Consequently, a greater number of natural frequencies may be extracted.

However, due to the limited length of the time window, even the peaks associated to the external loading acting on the bridge (i.e. traffic load) might appear in the response spectrum, making the identification process harder. Thus, to distinguish such peaks from structural modes, an automatic peak-picking procedure is performed on the Welch periodogram, and the first eight natural frequencies of the monitored structure may be identified. To emphasize the benefits that the proposed methodology may bring to the identification process, the same peak-picking technique is performed on the PSD of the original (raw) displacement signal, leading to the identification of the first natural frequency only. Such a comparison is represented in Fig. 7, where the modal natural frequencies are marked by vertical red lines and, then, further reported in Table 3, which coherently compare to analogous results provided in Ferrari et al. [6], namely frequencies identified through a classical FDD method on acceleration signals acquired out of standard wired accelerometer sensors.
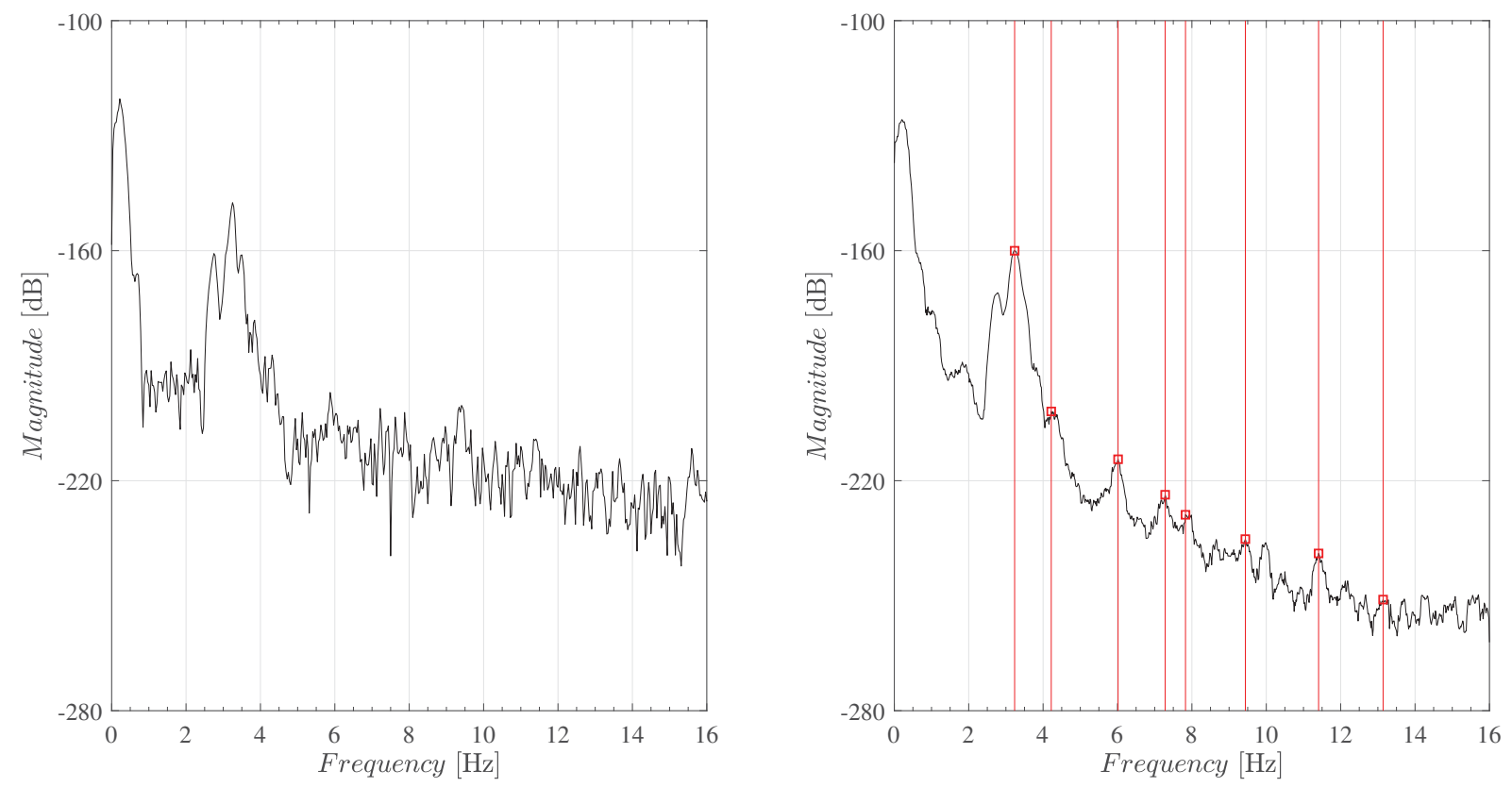

Figure 7: Brivio bridge identified natural frequencies from displacement signals. Peak-picking procedure on Welch periodogram: original (raw) displacement signal vs. HDF (enhanced) displacement signal.

Except for the first two and the sixth natural frequencies, which display a not negligible discrepancy with the respective outcomes deriving from a FDD-based inverse analysis on wired 


\begin{tabular}{lrrrrrrrr}
\hline Modes & I & II & III & IV & V & VI & VII & VIII \\
\hline$f_{i d, W D}[\mathrm{~Hz}]$ & 3.247 & 4.211 & 6.016 & 7.280 & 7.815 & 9.378 & 11.406 & 13.140 \\
$f_{i d, A C}[\mathrm{~Hz}]$ & 3.564 & 3.857 & 6.018 & 7.178 & 7.690 & 9.009 & 11.377 & 13.086 \\
\hline$\Delta[\%]$ & -8.89 & 9.18 & -0.03 & 1.42 & 1.63 & 4.10 & 0.25 & 0.41 \\
\hline
\end{tabular}

Table 3: Brivio bridge natural frequencies $f_{i d, W D}$ identified from a HDF displacement response signal (wireless sensor), compared to frequencies $f_{i d, A C}$ (Ferrari et al. [6]) identified from an acceleration response signal (wired sensor), and their variation.

accelerations, assumed here as reference, the results show a good agreement, as the percentage variation is in any case below $2 \%$.

Finally, from a FDD analysis (Pioldi et al. [10-12]) on displacement signals (corroborated as above by acceleration data), the bridge first span mode shapes, corresponding to the previously identified frequencies, are obtained and represented in following Fig. 8. In particular, the QDaedalus displacement data, enriched by reliable accelerations, as those acquired through a wireless detection system, represent the selected 8-channel input considered within the current analysis, for the representation of the mode shapes of the monitored structure.

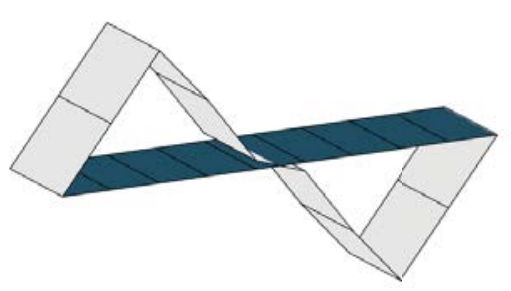

(a) Mode 1

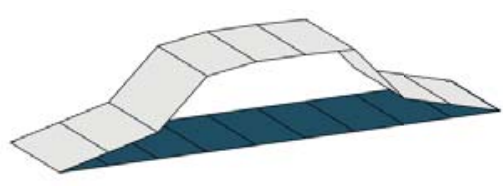

(c) Mode 3

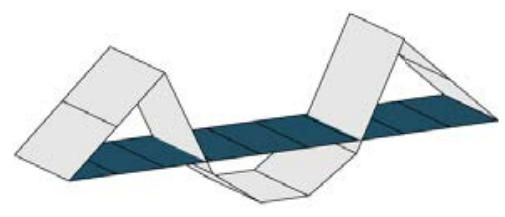

(e) Mode 5

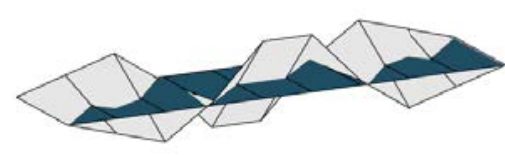

(g) Mode 7

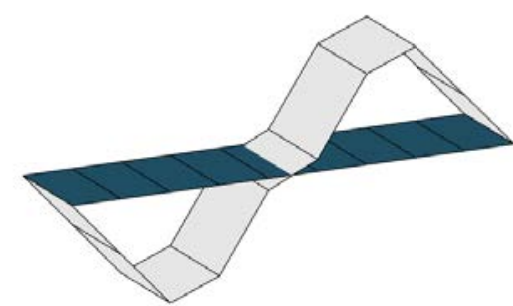

(b) Mode 2

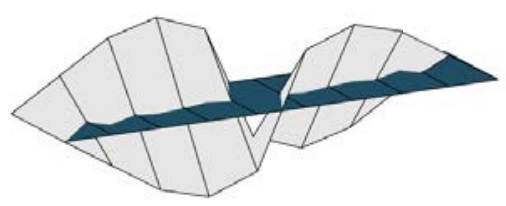

(d) Mode 4

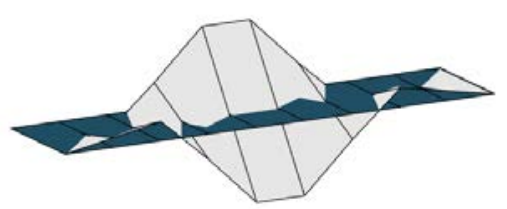

(f) Mode 6

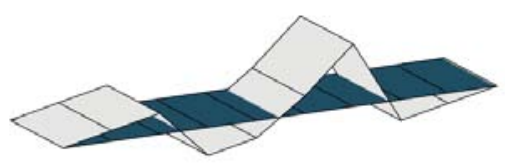

(h) Mode 8

Figure 8: FDD vibration mode shapes of Brivio bridge first span. 
Even concerning the vibration mode shapes, many analogies with the respective results reported in Ferrari et al. [6] may be observed. In particular, mode 1 and mode 2 show a very similar behaviour, although they are related to different natural frequencies. Moreover, most of the modes seem to be regular, characterized by bending or torsion, except for mode 7, in which bending and torsion appear to be coupled.

These similarities between the results may be considered as a further proof of the reliability of the proposed monitoring strategy, which provides an alternative approach aiming at evaluating the structural health condition of a generic civil structural system.

\section{CONCLUSIONS}

In this paper, an innovative monitoring methodology that integrates a denoising-based approach with a HDF-based strategy is proposed, for the structural health condition assessment of historic and strategic bridges. In particular, the main achievements that the present study has highlighted may be summarized as follows:

- the beneficial effect of the analyzed denoising technique is more pronounced within the time domain, where, after the DWT-based denoising application, the main signal features (i.e. peak value and RMS) may more clearly emerge;

- the acquired Brivio bridge acceleration and displacement response signals have been successfully denoised and, subsequently, involved within a HDF-based implementation, and an enhanced displacement response signal has been obtained;

- the output-only modal identification analysis performed on the enhanced displacement signal reveals the natural frequencies of the investigated structure, proving the effectiveness of the proposed methodology;

- by comparing the obtained results, by effective post-processing of response signals detected through wireless sensors, with those derived from signals acquired through standard wired sensors, no substantial differences emerge: this reinforces the belief that modern wireless sensor technology may become competitive at the signal acquisition stage, if adequately treated as here described, leading to reliable estimates.

In conclusion, the possibility of setting a monitoring platform that integrates a denoisingbased approach with a HDF-based strategy may allow the user to achieve a more complete and reliable description of specific response signals, bringing to light their more peculiar characteristics, in both time and frequency domains. In this sense, the post-processing methodology presented in this study, may constitute a useful tool within structural monitoring applications.

\section{Acknowledgments}

Public research support from "Fondi di Ricerca d'Ateneo ex 60\%" and a ministerial doctoral grant and funds at the ISA Doctoral School, University of Bergamo, Department of Engineering and Applied Sciences (Dalmine), are gratefully acknowledged. Prof. Chatzi and Dr. Dertimanis have received funding from Horizon 2020, the EU's Framework Programme for Research and Innovation, under grant agreement number 769373 (Project: FORESEE). 


\section{REFERENCES}

[1] Bürki, B., Guillaume, S., Sorber, P. and Oesch, H. (2010), DAEDALUS: a versatile usable digital clip-on measuring system for total stations. In: International Conference on Indoor Positioning and Indoor Navigation, Zürich, Switzerland, 15-17 September 2010.

[2] Chatzi, E.N. and Fuggini, C. (2012), Structural identification of a super-tall tower by GPS and accelerometer data fusion using a multi-rate Kalman filter. In: Proceedings of the 3rd International Symposium on Life-Cycle Civil Engineering, Delft, Netherlands, 3-6 October 2012, 10: 144-151.

[3] Chatzi, E.N. and Fuggini, C. (2015), Online correction of drift in Structural Identification using artificial white noise observations and an Unscented Kalman filter. Smart Structures and Systems, 16(2): 296-328.

[4] Ferrari, R., Froio, D., Chatzi, E.N., Gentile, C., Pioldi, F. and Rizzi, E. (2015), Experimental and numerical investigation for the structural characterization of a historic RC arch bridge. In: COMPDYN 2015, 5th ECCOMAS Thematic Conference on Computational Methods in Structural Dynamics and Earthquake Engineering, Crete Island, Greece, 25-27 May 2015, 1: 2337-2353, available online in Eccomas Proceedia, www.eccomasproceedia.org/conferences/thematic-conferences/compdyn-2015/3542.

[5] Ferrari, R., Pioldi, F., Rizzi, E., Gentile, C., Chatzi, E.N., Klis, R., Serantoni, E. and Wieser, A. (2015), Heterogeneous sensor fusion for reducing uncertainty in Structural Health Monitoring. In: UNCECOMP 2015, 1st ECCOMAS Thematic Conference on International Conference on Uncertainty Quantification in Computational Sciences and Engineering, Crete Island, Greece, 25-27 May 2015, pp. 511-528, available online in Eccomas Proceedia, www.eccomasproceedia.org/conferences/thematicconferences/uncecomp-2015/4289.

[6] Ferrari, R., Pioldi, F., Rizzi, E., Gentile, C., Chatzi, E.N., Serantoni, E. and Wieser, A. (2016), Fusion of wireless and non-contact technologies for the dynamic testing of a historic RC bridge. Measurement Science and Technology, 27(12): 1-19.

[7] Ferrari, R., Froio, D., Rizzi, E., Gentile, C. and Chatzi, E.N. (2018), Model updating of a historic concrete bridge by sensitivity- and global optimization-based Latin Hypercube Sampling. Engineering Structures, 179(January 2019): 139-160.

[8] Ferrari, R., Cocchetti, G. and Rizzi, E. (2019), Reference structural investigation on a 19th-century arch iron bridge loyal to design-stage conditions. International Journal of Architectural Heritage, Conservation, Analysis, and Restoration. Published online on 05 July 2019: 1-31. DOI: 10.1080/15583058.2019.1613453.

[9] Froio, D. and Zanchi, R. (2014), Finite element modelization and modal dynamic analyses of an historical reinforced concrete bridge with parabolic arches. MSc Thesis in Building Engineering, Advisor Rizzi E., Co-Advisor Ferrari R., University of Bergamo, School of Engineering, 232 pages. 
[10] Pioldi, F., Ferrari, R. and Rizzi, E. (2015), Output-only modal dynamic identification of frames by a refined FDD algorithm at seismic input and high damping. Mechanical Systems and Signal Processing, 68-69(February 2016):265-291.

[11] Pioldi, F., Ferrari, R. and Rizzi, E. (2015), Earthquake structural modal estimates of multi-storey frames by a refined FDD algorithm. Journal of Vibration and Control, 23(13):2037-2063.

[12] Pioldi, F., Ferrari, R. and Rizzi, E. (2017), Seismic FDD modal identification and monitoring of building properties from real strong-motion structural response signals. Structural Control and Health Monitoring, 24(11):1-20.

[13] Pioldi, F. and Rizzi, E. (2017), Refined Frequency Domain Decomposition modal dynamic identification from earthquake-induced structural responses. Meccanica, 52(13):3165-3179.

[14] Pioldi, F. and Rizzi, E. (2017), A refined Frequency Domain Decomposition tool for structural modal monitoring in earthquake engineering. Earthquake Engineering and Engineering Vibration, 16(3):627-648.

[15] Pioldi, F. and Rizzi, E. (2018), Assessment of Frequency versus Time Domain enhanced technique for response-only modal dynamic identification under seismic excitation. Bulletin of Earthquake Engineering, 16(3):1547-1570.

[16] Pioldi, F. and Rizzi, E. (2018), Earthquake-induced structural response output-only identification by two different Operational Modal Analysis techniques. Earthquake Engineering and Structural Dynamics, 47(1):257-264.

[17] Ravizza, G., Ferrari, R., Rizzi, E. and Chatzi, E.N. (2018), Effective heterogeneous data fusion procedure via Kalman filtering. Smart Structures and Systems, 22(5): 631-641.

[18] Ravizza, G., Ferrari, R., Rizzi, E., Dertimanis, V. and Chatzi, E.N. (2019), Denoising corrupted structural vibration response: critical comparison and assessment of related methods. In: Proceedings of the 7th International Conference on Computational Methods in Structural Dynamics and Earthquake Engineering (COMPDYN 2019), An ECCOMAS Thematic Conference, An IACM Special Interest Conference, M. Papadrakakis, M. Fragiadakis (eds.), 24-26 June 2019, Hersonissos, Crete Island, Greece, Institute of Structural Analysis and Antiseismic Research, National Technical University of Athens (NTUA), Conference Proceeding ID: 19291, Category: RSO2 - ALGORITHMS FOR STRUCTURAL HEALTH MONITORING, 12 pages.

[19] Ravizza, G., Ferrari, R., Rizzi, E., Dertimanis, V. and Chatzi, E.N. (2020), Critical assessment of two denoising techniques for purifying structural vibration response signals. To be submitted.

[20] Santarella, L. and Miozzi, E. (1948), Ponti Italiani in Cemento Armato. Milano: Hoepli. 


\section{EURODYN 2020}

\section{Proceedings of the}

XI International Conference on Structural Dynamics

M. Papadrakakis, M. Fragiadakis, C. Papadimitriou (Eds.)

First Edition, September 2020

ISBN (set): 978-618-85072-2-7

ISBN (vol I): 978-618-85072-0-3 